FRANCEMILSON GOULART DA SILVA

\title{
O HORMÔNIO TIROIDEANO INDUZ REORGANIZAÇÃO DO CITOESQUELETO DOS SOMATOTROFOS DE RATOS HIPOTIROIDEOS: POTENCIAL EFEITO SOBRE A ESTABILIDADE E TRADUÇÃO DO mRNA DO GH E SECREÇÃO DE GH.
}

Tese apresentada ao Instituto de Ciências Biomédicas da Universidade de São Paulo para obtenção do título de doutor em Ciências.

São Paulo

2008 
FRANCEMILSON GOULART DA SILVA

\section{O HORMÔNIO TIROIDEANO INDUZ REORGANIZAÇÃO DO CITOESQUELETO DOS SOMATOTROFOS DE RATOS HIPOTIROIDEOS: POTENCIAL EFEITO SOBRE A ESTABILIDADE E TRADUÇÃO DO MRNA DO GH E SECREÇÃO DE GH.}

Tese apresentada ao Instituto de Ciências Biomédicas da Universidade de São Paulo para obtenção do título de doutor em Ciências.

Orientadora: Profa. Dra. Maria Tereza Nunes

Área de concentração: Fisiologia Humana

São Paulo

2008 
DADOS DE CATALOGAÇÃO NA PUBLICAÇÃO (CIP)

Serviço de Biblioteca e Informação Biomédica do

Instituto de Ciências Biomédicas da Universidade de São Paulo

(C) reprodução total

Silva, Francemilson Goulart da.

O hormônio tiroideano induz reorganização do citoesqueleto dos somatotrofos de ratos hipotiroideos: potencial efeito sobre a estabilidade e tradução do mRNA do $\mathrm{GH}$ e secreção do $\mathrm{GH}$ / Francemilson Goulart da Silva. -- São Paulo, 2007.

Orientador: Maria Tereza Nunes.

Tese (Doutorado) - Universidade de São Paulo. Instituto de Ciências Biomédicas. Departamento de Fisiologia e Biofísica. Área de concentração: Fisiologia Humana. Linha de pesquisa: Hormônio tiroideano e citoesqueleto.

Versão do título para o inglês: Acute T3 administration induces reorganization of somatotroph's cytoskeleton of hypothyroid rats: potential effect on $6 \mathrm{H}$ mRNA stability and translation and $6 \mathrm{H}$ secretion.

Descritores: 1. Hormônio tiroideano 2. Citoesqueleto 3 . Tradução $\begin{array}{llll}4 . & \text { Estabilidade 5. EF1a } & \text { 6. Perfil polissomal I. Nunes, Maria Tereza }\end{array}$ II. Universidade de São Paulo. Instituto de Ciências Biomédicas. Programa de Pós-Graduação em Fisiologia Humana. III. Título. 
Candidato(a):

Título da Tese:
Francemilson Goulart da Silva.

O hormônio tiroideano induz reorganização do citoesqueleto dos somatotrofos de ratos hipotiroideos: potencial efeito sobre a estabilidade e tradução do mRNA do $6 \mathrm{H}$ e secreção do $6 \mathrm{H}$.

Orientador(a):

Maria Tereza Nunes.

A Comissão Julgadora dos trabalhos de Defesa da Tese de Doutorado, em sessão pública realizada a ......................................, considerou

\section{(X) Aprovado(a) ( ) Reprovado(a)}

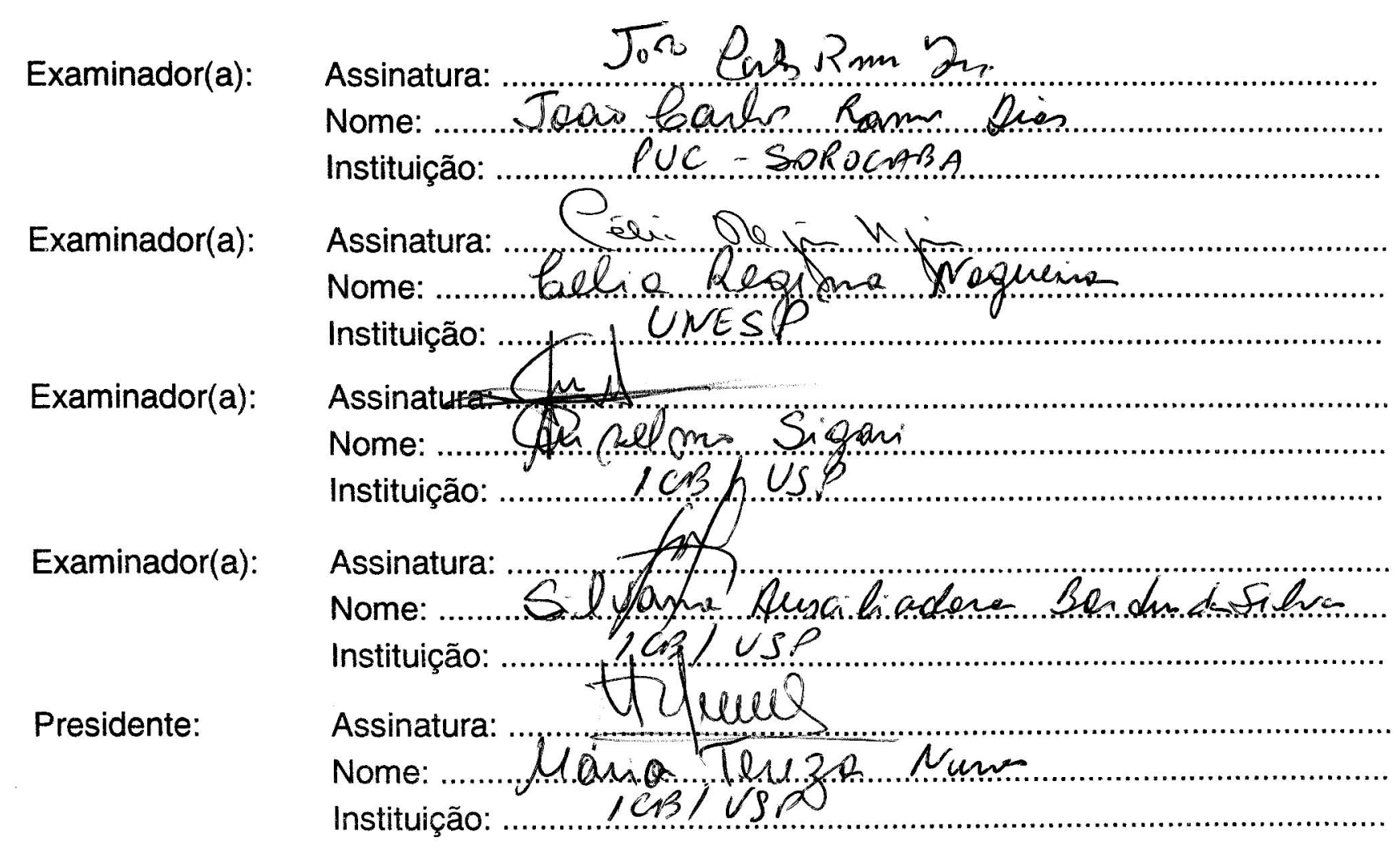




\section{Certificado}

Certificamos que o protocolo registrado sob $n^{\circ} 076$ nas fls. 18 do livro 2 para uso de animais em experimentaçāo, sob a responsabilidade da Profa. Dra. Maria Tereza Nunes, Coordenadora dá Linha de Pesquisa "Regulação da estabilidade do RNAm do GH pelo hormônio tiroideano: Possivel envolvimento do citoesqueleto" do qual participou(aram) o(s) aluno(s): Francemilson Goulart da Silva, está de acordo com os Principios Éticos de Experimentação Animal adotado pelo Colégio Brasileiro de Experimentação Animal (COBEA) e foi aprovado pela COMISSÃO DE ÉTICA EM EXPERIMENTAÇÃO ANIMAL (CEEA) em 23.08.2005.

São Paulo, 23 de agostó de 2005.

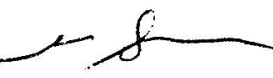

Profa. Dra. Marília C. Leite Seelaender Coordenadora da CEEA - ICB/USP

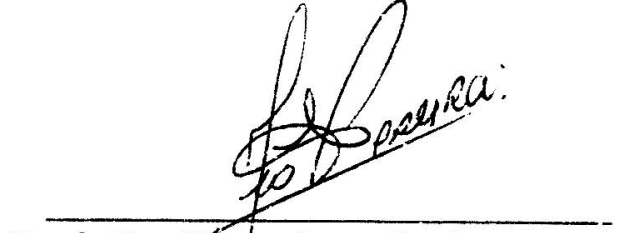

Prof. Dr. Francisco Carlos Pereira Secretário da CEEA 


\section{Agradecimentos}

Á Deus, pela coragem para iniciar a pós-graduação num momento de muita imaturidade. Por promover meu amadurecimento pessoal e profissional, por nos ajudar a colocar em prática nossas idéias e por nos ajudar na realização e na compressão dos experimentos.

À minha mentora e chefe, Maria Tereza Nunes, pelo tempo que gastamos juntos, por tudo que aprendi com ela e pelo que ainda aprenderei, pelos conselhos pessoais e científicos, pelas confraternizações, pela sua valiosa amizade, pelo seu valioso carinho e, acima de tudo, pela sua grande empatia.

Aos meus pais, Francisco Goulart da Silva e Maria Cirene da Silva por contribuirem na minha formação, pelos seus valores, pelas suas crenças, pelo seu apoio, amor e votos de sucesso, mas acima de tudo, obrigado por aceitarem a minha ausência, assim como as chamadas telefônicas não atendidas. Obrigado por entenderem tudo isso e mesmo assim me apoiarem.

Aos meus queridos irmãos, Ademilson Goulart da Silva e Gisele Goulart da Silva que são co-autores dessa conquista já que apostaram em mim e com incentivo tornaram possível a realização desse dia. Pelo tempo que passamos separados e pelo que deixamos de conquistar juntos, mas acima de tudo por aquilo que conquistamos longe um dos outros. Obrigado por existirem porque a sua existência fez desse dia realidade.

À Leonice Poyares pela sua compreensão nos momentos difíceis, pelo seu apoio nos momentos de crise, pelo seu amor nos momentos de carência, pela sua amizade e dedicação nos momentos de necessidade e pela sua disposição em ajudar. Obrigado por assumir o papel de mãe na vida de todos os que estão próximos a você. Você é, e continuará sendo, muito especial para todos nós.

Aos meus amigos de laboratório pelo suporte nos dias agitados de experimentos, pelos risos nos momentos de ócio e pelas discussões científicas ou pouco científicas. Àqueles que continuam no grupo, Gisele Giannocco, Silvania Texeira, Carolina Serrano, Thaís de Castro, Janaína Sena, Érica Brunetto, Lucas Guimarães, Rafael Croffi, Rafael Júnior e Andréia I Pin e as novas mestrandas do grupo, Paula Bargi e Jamile Calil. Àqueles que deixaram o grupo, Marta Mariúba, Paula Juliana, Kely de Picoli, Silvia Cristina, Mônica, Marcelo e Patrícia Branco e Rogério Sertié. Enfim, para todos os que continuam ou que já estiveram, obrigado por tudo!!!

Aos professores dos Departamentos de Fisiologia e Biofísica e Biologia Tecidual e do desenvolvimento que permitiram o uso de seu espaço físico, de materiais e equipamentos, mas acima de tudo isso, pela disposição em ajudar nos momentos de dúvida e necessidade.

Ao pessoal do biotério, Claudio, Wilson, Robertinho e Maria Alice, responsáveis pelo cuidado com nossos animais. Obrigado pela sua dedicação aos animais e pelo seu apoio as nossas pesquisas. 
Aos meus amigos de curtição, baladas e risadas, Cristiano Tonéis, Renato Mayrinck, Juliano, Fernando albuquerque, Almir, Edson Manzatto, Fabinho e companhia limitada. Obrigado pelo momentos de lazer, pelas brincadeiras e pelas festas. Com certeza, as festas e baladas não contribuiram com minha formação, mas a amizade de todos vocês sim.

Ao pessoal da secretaria, José Maria, Celso, Hiroko, Itamar, Leila, Patrícia e Claudia por toda ajuda nas questões burocráticas e administrativas.

À minha professora de Fisiologia da gradução, Luciana Portelinha, pelo incentivo para a pós-graduação, pelas aulas de fisiologia e abordagem pedagógica, por despertar em mim o interesse e amor à ciência, fatores que foram essenciais para minha opção por fisiologia.

Aos meus professores e colegas da graduação, pelos anos que passamos juntos na UNOESTE, pelas provas e testes na arte do cuidar e do ser enfermeiro e pelos desafios impostos pela profissão. Exerci por pouco tempo a enfermagem, mas esse pouco tempo, foi suficiente para perceber que a enfermagem foi minha melhor escolha para graduação.

Àqueles que me apoiaram e apostaram em mim quando vim para São Paulo; pessoas como Lucileide e Margo que foram fundamentais no início do meu mestrado e que com carinho e amor me receberam em suas casas e preparam tudo o que foi necessário para minha nova vida.

Á Mariene, pelos nossos desencontros e encontros e por tudo que passamos juntos; pela nossa amizade e pelo forte carinho que sentimos.

Ao Cristiano, meu amigo, pelos seus conselhos, pelas discussões filosóficas e pelo companheirismo.

Às instituições de fomento, FAPESP e CNPq, que com apoio financeiro permitiram a realização desse trabalho, assim como ofereceram suporte para viagens internacionais e nacionais, eventos que contribuiram com o nosso projeto e com minha formação acadêmica.

Enfim, para todos aqueles que me ajudaram no início, no meio e no final da minha pósgraduação, com apoio técnico e científico; pessoas das quais jamais me esquecerei e que, com certeza, as palavras não poderão expressar o seu valor e significado. 
A maior beleza do ser humano é ser humano Diogo Montana 


\section{RESUMO}

O T3 aumenta a poliadenilação e estabilidade do GH mRNA. O citoesqueleto (Cy) participa da estabilidade e tradução de mRNAs, pois fatores, como o EF $1 \alpha$, ligam alguns transcritos a ele, aumentando sua estabilidade e tradução. Cy também participa dos processos secretores celulares. Observamos que no hipotiroidismo (Tx), há um desarranjo do Cy nos somatotrofos que é revertido pela administração aguda de T3. Neste estudo avaliamos a ligação do EF $1 \alpha \mathrm{e}$ do GH mRNA ao Cy e, deste aos polissomos, na hipófise, e a expressão do IGF-I mRNA hepático, em ratos controle e Tx tratados com T3 ou salina, e sacrificados após $30 \mathrm{~min}$. Observamos redução da F-actina, da ligação do EF $1 \alpha$ e GH mRNA a ela, do GH mRNA nos polissomos, e da expressão de IGF-I mRNA hepático, nos ratos $T x$, o que indicou redução da síntese e secreção do $\mathrm{GH}$. A administração de T3 estimulou esses processos, aumentando a estabilidade, tradução do $\mathrm{GH}$ mRNA e a secreção de $\mathrm{GH}$, o que ocorreu em paralelo ao rearranjo do $\mathrm{Cy}$, indicando uma ação não genômica do T3. 


\begin{abstract}
T3 increases GH mRNA poly-A tail and stability. Cytoskeleton (Cy) plays a part on mRNA stability and translation, since factors, like EF $1 \alpha$, can bind some transcripts to it, improving stability and translation efficiency. Cy is also involved in cellular secretory process. We showed that somatotropes Cy is disrupted in hypothyroidism (Tx), and rearranged by acute T3 treatment. In this study we investigated the binding of EF $1 \alpha$ and GH mRNA to $C y$ and of GH mRNA to polysomes in pituitary, as well as the liver IGF-I mRNA content, in control and Tx rats treated with $\mathrm{T} 3$ or saline, and killed 30 min thereafter. We observed that Tx reduced F-actin content, EF $1 \alpha$ and $\mathrm{GH}$ mRNA binding to it, $\mathrm{GH}$ mRNA recruitment to polysomes, in pituitary, and IGF-I mRNA expression in liver, which indicates that $\mathrm{GH}$ synthesis and secretion are impaired. Acute T3 treatment stimulated all these process, indicating that stability, translation of $\mathrm{GH}$ mRNA and $\mathrm{GH}$ secretion were restored. These events occurred in parallel to the Cy rearrangement, which strongly indicates a non genomic effect of T3.
\end{abstract}




\section{LISTA DE ABREVIATURAS}

Actina $\mathrm{F}$ - actina filamentosa ou actina em polímeros. São os microfilamentos

Actina $G$ - actina monomérica ou globular

Akt - serina/treonina quinase, também conhecida como PKB (proteína quinase B)

Animais FO - animais falso-operados

Animais Tx - animais tiroidectomizados

D2 - Desiodase do tipo 2 (enzima conversora de T4 à T3)

Domínio RGD - sequiência de aminoácidos onde $R$ é arginina, $G$ é glicina e $D$ é ácido aspártico

eEF $1 \alpha$ : Fator de alongamento da cadeia polipeptídica $1 \alpha$ de células eucariontes

eEF2 - Fator de alongamento da cadeia polipeptídica - isoforma 2

eIF2 - Fator de iniciação da tradução - isoforma 2 de células eucariontes

eIF3 - Fator de iniciação da tradução - isoforma 3 de células eucariontes

eIF4F - Complexo de fatores de iniciação da tradução presentes em células eucariontes

eNOS - Óxido Nítrico Sintase - enzima produtora de óxido nítrico

ERK - Proteína quinase regulada pelo extracelular

GAPs - proteínas ativadoras de GTPases

GDI - fator inibitório da dissociação de guanosina

GDP - Difosfato de guanosina

GEFs - fatores de troca de nucleotídeos de guanosina

GH - Hormônio do Crescimento

GLUT-4 - Transportador de glicose regulado pela insulina

GTP - Trifosfato de guanosina

HTs - Hormônios Tirodeanos

IGF-1 - Fator de crescimento insulina-símile do tipo 1, também conhecida como somatomedinas.

Il-2 - Interleucina 2

INF- $\gamma$ - Interferon Gama

Integrina $\alpha \mathrm{V} \beta 3$ - umas das 24 isoformas de integrina

MAPK - Proteína quinase ativada por mitógenos 
$\mathrm{NO}$ - Óxido Nítrico

P85 - subunidade regulatória da PI3-K

PABP - Proteína de ligação à cauda poli A do mRNA

PAP - poli A polimerase

PI3-K - Fosfatidilinositol 3 quinase

$\mathrm{PKC}$ - Proteína quinase C

Real time PCR - Reação em cadeia de polimerase em tempo real

Rho - proteínas de baixo peso molecular ligadas ao GTP

RNA - Ácido Ribonucléico. São encontrados os seguintes tipos de RNAs: RNA mensageiro (mRNA), RNA de transferência (tRNA), RNA ribossomal (rRNA), RNA de interferência e microRNAs.

TR $\beta$ - Receptor para Hormônios Tiroideanos do tipo $\beta$

TR $\alpha 1$ - Receptor para Hormônios Tiroideanos do tipo $\alpha 1$

TRE - Elemento Responsivo aos Hormônios Tiroideanos 


\section{SUMÁRIO}

1 INTRODUÇÃO

2 MATERIAL E MÉTODOS 21

$\begin{array}{ll}2.1 \text { PROTOCOLO ANIMAL } & 21\end{array}$

$\begin{array}{ll}2.2 \text { PROTOCOLO EXPERIMENTAL } & 22\end{array}$

2.2.1 Perfil Polissomal e Northern blotting $\quad 22$

2.2.2 Avaliação da expressão da Actina Polimerizada (actina F) e Não 26 Polimerizada (actina G)

2.2.3 Ensaio para avaliação da taxa de ligação do eEF $1 \alpha$ com o citoesqueleto 28

2.2.4 Ensaio para avaliar o conteúdo do mRNA de GH ligado ao citoesqueleto 28

2.2.5 Avaliação do conteúdo hepático do mRNA de IGF-1 31

2.2.6 Análise Estatística

3 RESULTADOS

Confirmação dos estados eutiroideos e hipotiroideos por meio de parâmetros 33 funcionais.

3.1 Análise do Perfil Polissomal hipofisário (detecção do mRNA do GH) de ratos 36 eu, hipo e hipotiroideos tratados agudamente com T3.

3.2 Efeito do T3 sobre o remodelamento da actina: Análise do conteúdo 38 hipofisário de actina polimerizada (actina F) e não polimerizada (actina G).

3.3 Efeito do T3 sobre a taxa de associação de eEF $1 \alpha$ ao citoesqueleto de actina: Análise do conteúdo de eEF 1 nas frações polimerizada (actina $F$ ) e não polimerizada da actina (actina $G$ ).

3.4 Efeito do T3 sobre a associação do mRNA do GH ao citoesqueleto de actina. Análise do conteúdo de mRNA do GH na fração polimerizada da actina (actina F).

3.5 Efeito do T3 sobre a expressão hepática do mRNA do IGF-I por real time 44 $P C R$. Análise do efeito do T3 sobre a secreção de GH.

4 DISCUSSÃO 46

REFERENCIAS BIBLIOGRÁFICAS 


\section{INTRODUÇÃO}

Os hormônios tiroideanos (HTs) estão envolvidos em vários processos biológicos relacionados ao crescimento, desenvolvimento e metabolismo. Para que muitas dessas ações aconteçam faz-se necessária a interação dos HTs com receptores que se encontram acoplados à sequiências específicas de determinados genes, conhecidas como elementos responsivos aos HTs (TREs). As ações decorrentes dessa interação são chamadas de genômicas, pois estimulam ou reprimem a expressão de genes (RIBEIRO et al., 1995; IWASAKI et al., 2004; SHUPNIK e RIDGWAY, 1985). Mais recentemente, descobriu-se que certas proteínas de membrana podem se ligar aos HTs e recrutar enzimas citosólicas, responsáveis por alterações da função celular (CODY et al., 2007; DAVIS et al., 2006; BERGH et al., 2005). Adicionalmente, os próprios receptores nucleares dos HTs podem, antes de se dirigirem ao núcleo, ser acionados pelos HTs e provocar ativação de quinases (STOREY et al., 2006). Esses efeitos dependentes da interação dos HTs com receptores citosólicos ou de membrana plasmática são reconhecidos como decorrentes das ações não genômicas ou extranucleares dos HTs.

Alguns efeitos não gênomicos dos HTs já haviam sido evidenciados ou, pelo menos, suspeitava-se de sua existência, antes mesmo da caracterização dos receptores nucleares, mas com a descoberta destes receptores, tais especulações foram deixadas em segundo plano (NAKAMURA et al., 1983; NARAYAN et al., 1984; SAP et al., 1986). Entretanto, estes efeitos voltaram a ser enfocados após a descoberta de ações dos HTs que se instalavam rapidamente segundos e minutos (MEZOSI et al., 2005; DAVIS et al., 2004; KAVOK et al., 2001), (2) e que persistiam na presença de inibidores da transcrição gênica (LEI et al., 2003; GOUVEIA et al., 2001, 1990; DAVIS e DAVIS, 1996). A rapidez com que esses efeitos aconteciam conduziram uma série de pesquisas elucidativas para traçar o mecanismo de ação não genômica dos HTs.

Uma das primeiras ações extranucleares dos HTs descritas na literatura partiu de estudos de Leonard et al. (1990) que descreveram uma rápida diminuição da atividade da desiodase do tipo 2 - D2 (enzima que converte T4 a T3) frente à administração de T4 (20 min) em astrócitos cultivados em meio deficiente de hormônio tiroideano, efeito que persistiu na presença de ciclohexamida e actinomicina $\mathrm{D}$, conhecidos inibidores da síntese protéica e transcrição gênica, respectivamente. No entanto, observou-se que a diminuição da atividade da D2, pela adição de 
T4, assim como de T3 reverso, à cultura de astrócitos, foi dependente da polimerização de actina do citoesqueleto, uma vez que o bloqueio da mesma por citocalasina B evitou a queda da atividade da D2 (FARWELL et al., 1990; FARWELL et al., 1992; LEONARD e FARWELL, 1997; SIEGRIST-KAISER et al., 1990; SAFRAN et al., 1992; SAFRAN et al., 1993). Esse efeito foi observado em 20 minutos, pouco tempo para que ocorresse a síntese de uma proteína e, ainda, pelo T4, ao qual a afinidade dos receptores de HT é 10 vezes inferior a do T3, o que corroborou os dados anteriores do mesmo grupo sobre ser esse efeito resultante de uma ação não genômica dos HTs.

Além de T4 e T3 reverso, há relatos de que o próprio T2 exerce efeitos biológicos importantes para o metabolismo celular. Seu principal sítio de ação são as mitocôndrias, onde estimula a beta-oxidação de lipídeos, com formação de acetil-CoA e produção de energia. Apesar do próprio T3 exercer efeito sobre a atividade mitocondrial, o T2 é considerado como sendo mais potente do que o T3 nessa ação (LANNI et al, 1993; CIMMINO et al., 1996; GOGLIA F., 2005; ARNOLD S., 1998). Vale lembrar que o T3 foi considerado durante muito tempo o hormônio biologicamente ativo, enquanto seus metabólitos (T3 reverso e T2), ou próhormônio (T4) eram considerados, respectivamente, como destituídos de, ou com pouca, atividade biológica, o que é verdadeiro caso a referência seja a sua ação nuclear ou genômica.

Em uma revisão feita por Davis (1996) uma série de ações dos HTs que não envolvem receptores nucleares foi apontada, tais como: redução da inativação do canal de sódio, aumento da atividade da cálcio ATPase, aumento da captação de glicose, polimerização de actina, com diminuição concomitante da atividade da D2, aumento da captação de oxigênio, bem como da atividade da ATP sintase e da citocromo oxidase. Adicionalmente, demonstrou-se uma ação dos HTs na regulação pós-transcricional da expressão de genes, como a da enzima málica e apolipoproteina AI.

Estudos desenvolvidos em nosso laboratório demonstraram que o transcrito do GH é regulado pós-transcricionalmente pelos HTs. Tais estudos foram realizados em ratos hipotiroideos os quais, após 30 min da administração de doses sub-fisiológicas de T4 (25\% da dose de reposição fisiológica), apresentaram elevação de aproximadamente duas vezes no conteúdo do mRNA do GH. Esse efeito foi atribuído à maior desiodação de T4 a T3 pela elevada 
atividade D2 hipofisária dos ratos hipotiroideos, já que a administração de T3 reverso, inibidor competitivo da D2, impediu a sua manifestação (VOLPATO e NUNES, 2001).

Em outro estudo foi possível identificar um aumento do conteúdo de mRNA do GH em ratos hipotiroideos, após 30 min da administração de doses supra-fisiológicas de T3. A análise molecular do mRNA do GH destes animais demonstrou a presença de maior número de resíduos de adenina na sua cauda poli-A, processo conhecido como poliadenilação, do qual participam a enzima poli-A polimerase (PAP) nuclear e, a seguir, citoplasmática.

Em geral, quanto maior o grau de poliadenilação do mRNA, maior é a sua estabilidade (aumento da meia-vida), pois à cauda poli-A se associam proteínas (proteínas ligantes da cauda poli-A: PABP) que a protegem de clivagem pelas RNases. Essas duas enzimas, portanto, participam do processamento pós-transcricional do mRNA, o que sugere claramente uma ação do T3 nesta etapa da regulação da expressão gênica do GH (VOLPATO et al., 2000). Vale salientar que essas enzimas estão ligadas ao citoesqueleto (MOHR et al., 2001; SCHRODER et al., 1982), o que nos leva a pensar que uma desorganização deste possa provocar prejuízo na atividade de PAP e PABP, causando diminuição do comprimento da cauda poli A de mRNAs e, consequentemente, diminuição da estabilidade do transcrito.

No entanto, nada sabíamos sobre as repercussões do hipotiroidismo sobre o citoesqueleto de somatotrofos, o que nos conduziu aos primeiros estudos para avaliação do seu grau de organização nas células da adenohipófise e, em particular, nos somatotrofos, nos quais realizamos análise imuno-histoquímica, para identificação do GH e da actina F.

Assim, observamos um desarranjo do citoesqueleto na totalidade das células da adenohipófise dos animais hipotiroideos, caracterizado por uma baixa marcação de actina $F$, efeito que se estendeu aos somatotrofos (GOULART DA SILVA et. al., 2006). Em paralelo, detectamos diminuição do conteúdo hipofisário de $\mathrm{GH}$, o que pode ser devido a uma menor síntese protéica, já que os HTs são importantes para transcrição gênica do GH (VOLPATO e NUNES, 1994). Os dados de imuno-histoquímica também revelaram a presença de poucos grânulos de $\mathrm{GH}$, os quais se apresentaram distribuídos principalmente, senão totalmente, na periferia dos somatotrofos, o que sugere uma menor secreção do $\mathrm{GH}$, provavelmente por um desarranjo do citoesqueleto, o qual desempenha um papel crucial no tráfego de vesículas. 
A administração aguda de T3 foi capaz de promover a polimerização de actina, reorganizando o citoesqueleto dessas células, o que é um forte indício de uma ação não genômica dos HTs (GOULART DA SILVA et al., 2006). Concomitante a essa reorganização do citoesqueleto, observou-se marcante redução de marcação de GH na periferia e aumento da mesma na região perinuclear dos somatotrofos, sugerindo, respectivamente, um efeito do T3 na secreção e síntese de GH..

O aumento da síntese do GH pode ter ocorrido por aumento da eficiência de tradução do mRNA, uma vez que se supõe, pelo maior grau de poliadenilação do mRNA do GH (VOLPATO et al., 2000), que ele se encontre mais protegido da ação de RNAses, o que aumentaria o seu pool para a tradução, um efeito dependente de T3 e que parece envolver o citoesqueleto, já que enzimas que sabidamente promovem a estabilidade de mRNA estão associadas a ele. Além disso, existem proteínas envolvidas com a tradução ligadas ao citoesqueleto, o que o torna importante também para a tradução do transcrito (SHANINA et al., 2001; PINCHEIRA et al., 2001; SHESTAKOVA et al., 1993), dado que pode reforçar o efeito indireto do T3 sobre a eficiência da tradução do transcrito do GH.

Os HTs, portanto, exercem importante papel na organização do citoesqueleto dos somatotrofos, o que também foi observado em outros tipos celulares, como astrócitos (LEONARD et al., 1997), sendo que esse efeito poderia justificar o aumento da estabilidade do mRNA e da síntese do GH. Sabe-se que as proteínas da família Rho estão envolvidas no processo de polimerização da actina, o que as coloca como potenciais alvos dos HTs, porém, isso precisa ser melhor investigado.

As evidências de ações não genômicas dos HTs mobilizaram a comunidade científica para descrever as vias envolvidas nesses efeitos. Nesse sentido surgiram várias estudos, e um deles demonstrou que o T4, por meio da ativação da MAPK (ERK1/2), era capaz de promover a fosforilação do receptor dos HTs, o que aumentava a sua afinidade ao T3 (DAVIS et al, 2000). Além do T4, o próprio T3 é capaz de aumentar a atividade de PKC, o que foi visto em linfócitos T. Nessas células a atividade de PKC induzida pelo T3 levou a liberação de citocinas (Il-2 e INF$\gamma$ ), efeito que foi responsável por maior proliferação de linfócitos T e B o que induziu a melhora da resposta imune (KLECHA et al., 2006). Vale salientar que os processos de exocitose 
dependem do citoesqueleto (BANOVAC e KOREN, 2000) e, desta forma, a liberação de citocinas pelos linfócitos também depende do citoesqueleto, estrutura que tem se mostrado alvo dos HTs. Desta forma, não somente o T4, mas o próprio T3 exerce efeitos não genômicos.

O citoesqueleto é um conjunto de filamentos protéicos formados por microfilamentos, microtúbulos e filamentos intermediários, cuja importância baseia-se, entre outras ações, no fato de participarem do tráfego de vesículas e outros elementos através do ancoramento feito por proteínas motoras, como demonstrado para a D2 (STACHELEK et al., 2000). Os microfilamentos são formados pela polimerização de actina (actina F), cujo bloqueio afeta a integridade do citoesqueleto, fazendo com que muitas das funções desempenhadas por ele deixem de ser observadas.

A polimerização de actina (actina $\mathrm{F}$ ) é um processo que envolve a ativação de proteínas $\mathrm{G}$ de baixo peso molecular pertencentes à família Rho, com atividade GTPásica, ou seja, hidrolisam o GTP (Trifosfato de guanosina) em GDP (Difosfato de guanosina). Essas proteínas ciclam entre um estado inativo (ligado ao GDP) e ativo (ligado ao GTP), quando interagem com diversas proteínas efetoras. O ciclo é regulado por fatores que favorecem a troca de GDP por GTP, os GEFs (fatores de troca de nucleotídeos de guanosina), pelo GDI (fator inibitório da dissociação de guanosina), que forma um complexo com Rho no citoplasma e por proteínas que ativam a quebra de GTP (GAPs - proteínas ativadoras de GTPases), inativando a proteína Rho. Proteínas Rho são isopreniladas e, quando ativadas, migram para a membrana celular para interagir com os seus efetores. Quando a célula é estimulada por fatores de crescimento ou hormônios, a via de transdução acionada é responsável pela ativação de um ou mais GEFs, resultando na ativação de proteínas Rho e seus efetores, responsáveis pela polimerização de actina do citoesqueleto (NOBES e HALL, 1994; VAN AELST e D'SOUZA-SCHOREY, 1997; HALL, 1998; WATANABE et al., 2005).

Essas Rho GTPases são moduladas por vários fatores, dentre eles a PKC. Sabe-se que várias isoformas de PKC estão envolvidas com migração celular, evento que modifica toda a estrutura da célula e que mobiliza o citoesqueleto; nesses estudos observou-se que a diminuição da atividade de PKC comprometia a migração celular e, consequentemente, a vida da célula, já que durante a migração a célula estabelece contatos com a matriz celular que são importantes para sua sobrevivência (LARSSON, 2006). Este fato nos permite inferir que o aumento da 
atividade de PKC induz a ativação das proteínas da família Rho GTPases, o que leva a polimerização de actina. Outra enzima envolvida com as proteínas da família Rho GTPases é a PI3-K, enzima que faz parte da complexa via de sinalização da insulina. A ativação de PI3-K promove, entre outras ações, a translocação de GLUT4 (uma das isoformas de transportador de glicose) para a membrana plasmática de adipócitos, músculo esquelético e cardíaco. É interessante lembrar que a translocação de GLUT4 e, consequentemente, sua inserção na membrana plasmática, são processos que dependem de microfilamentos e microtúbulos (MCCARTHY et al., 2006; LIU et al., 2006; KANZAKI e PESSIN, 2001).

Os HTs também utilizam a PI3-K para algumas de suas ações, como as observadas no endotélio de vasos sangüíneos. Nesse caso o próprio receptor nuclear dos HTs - TR $\alpha 1$, que ainda está localizado no citosol, interage com a sub-unidade p85 da PI3-K, ativando a Akt. Uma vez ativa, a Akt aumenta a atividade de eNOS, levando a maior produção de óxido nítrico (NO) e queda de pressão arterial por vasodilatação (HIROI, et al., 2006). Em outro modelo experimental demonstrou-se que o TR $\beta$, e não TR $\alpha$, associou-se à PI3-K, o que levou ao aumento da condutância do canal de potássio em linhagem de células da hipófise - $\mathrm{GH}_{4} \mathrm{C}_{1}$ (STOREY et al., 2006). Vários outros efeitos envolvendo HTs e PI3-K foram descritos o que torna essa via importante para alguns efeitos extranucleares dos HTs.

Sabia-se que a PKC estava envolvida com alguns efeitos dos HTs, mas o mecanismo pelo qual ela era estimulada permanecia desconhecido. Entretanto, Davis, em 2005, publicou um artigo de revisão, em que descreveu um "provável" receptor de membrana plasmática para HTs, pertencente à família das integrinas. As integrinas são proteínas transmembrana com domínios voltados para o extracelular e para o intracelular. Esses domínios participam da adesão da célula ao substrato de matriz por se prenderem ao citoesqueleto (porção intracelular) e à proteínas de matriz extracelular, por meio de seu domínio RGD (porção extracelular). No entanto, sua função como proteínas transmembrana vai muito além disso, já que se sabe que elas fazem parte de vias de sinalização utilizadas por hormônios, como os tiroideanos, conforme descrito por Davis.

Davis identificou a integrina $\alpha \mathrm{V} \beta 3$ como a proteína (receptor) que reconhece os HTs. Em seus estudos com células endoteliais, ele observou a interação dos HTs com a integrina $\alpha \mathrm{V} \beta 3$ próximo do local de reconhecimento da sequiência RGD de proteínas de matriz extracelular. 
Segue-se a esta interação, uma elevação da atividade da PKC e da MAPK. Sabe-se que a interação ligante-receptor altera a conformação da proteína $\mathrm{G}$, levando à dissociação de suas subunidades. A sub-unidade $\alpha$ se liga ao GTP e ativa a fosfolipase C (PLC), esta, gera, a partir de fosfolipídeos de membrana, o trifosfato de inositol (IP3) e o diacilglicerol. O IP3 aumenta a liberação de cálcio no intracelular, que junto com diacilglicerol ativa a PKC. No modelo de Davis, a ativação de PKC pela interação dos HTs com a integrina $\alpha \mathrm{V} \beta 3$, provoca aumento da atividade de MAPK, o que por sua vez estimula a proliferação celular e, nesse caso, proliferação das células endoteliais, induzindo a angiogênese (DAVIS et al., 2005).

A caracterização de integrinas como receptores de membrana para os HTs, assim como de uma via de sinalização envolvendo PKC e MAPK, representou um grande avanço para a compreensão dos mecanismos moleculares envolvidos na ação não genômica dos HTs. Entretanto, esta não é a única via, pois existem muitos efeitos dependentes de PI3-K e que, aparentemente, não dependem de PKC ou integrina, mas da associação entre receptor citosólico de HTs (os mesmos que migram para o núcleo) com a PI3-K ( CAO et al., 2005).

Recentemente, demonstrou-se que a PKC, e não a MAPK, também está envolvida no processo de regulação da síntese protéica. Os estudos conduzidos nessa direção apontam que a ativação da PKC aumenta a afinidade/interação de transcritos à proteínas citosólicas, conhecidas como trans-acting factors; sendo o oposto observado quando a atividade da PKC é bloqueada, o que leva a uma diminuição da eficiência de tradução dos mRNAs (SIDIROPOULOS et al., 2006).

Conforme apontado anteriormente, o citoesqueleto exerce um papel fundamental na tradução, já que proteínas envolvidas com a estabilidade do transcrito (Poli-A polimerase e PABP) encontram-se associadas a ele. No entanto, há evidências adicionais de que essa interação posiciona os mRNAs em locais estratégicos no meio intracelular o que, além de favorecer a estabilidade do transcrito também compartimentaliza a sua tradução (HESKETH et al., 1996). A localização inapropriada do transcrito pode deixá-lo susceptível a ação de fatores deletérios, levando à formação de proteína anômala. Esses efeitos dependem do citoesqueleto e parecem envolver as proteínas motoras presentes nos microfilamentos e microtúbulos (MÜNCHOW et al., 1999; LIPSHITZ e SMIBERT, 2000; TEKOTTE e DAVIS, 2002). 
Outro ponto importante é que essa ligação de transcritos ao citoesqueleto não se dá diretamente, já que proteínas que fixam o mRNA ao citoesqueleto foram identificadas (JANSEN, 1999). Entre essas proteínas está o fator de alongamento da cadeia polipeptídica 1 alfa (eEF $1 \alpha$ : eukaryotic elongation factor $1 \alpha$ ), cuja função conhecida é ligar o tRNA conjugado ao aminoácido ao complexo ribossomal durante a tradução, o que o torna uma das peças fundamentais para a síntese protéica (NEGRUTSHII et al., 1998); no entanto, ele parece exercer uma outra função, que é fixar os transcritos ao citoesqueleto (LIU et al., 2002; CONDEELIS, 1995). Sabe-se, desde 1991, da capacidade de eEF $1 \alpha$ de se ligar ao citoesqueleto, o que foi observado, primeiro em protozoários (YANG, 1991) e depois em algas (COLLINGS, 1994). No entanto, nada se sabia de seu possível papel como ancorador de mRNAs ao citoesqueleto, até que, estudos desenvolvidos por Liu (2002) demonstraram que, na ausência ou mesmo mutação do sítio de ligação do eEF $1 \alpha$ ao citoesqueleto, ocorria menor associação entre o transcrito e a actina $\mathrm{F}$.

Desta forma, considerando os nossos dados de: (a) aumento da poliadenilação do mRNA do $\mathrm{GH}$, que proporcionaria maior estabilidade ao transcrito e, (b) reorganização do citoesqueleto de somatotrofos de ratos hipotiroideos, ambos observados após 30 min da administração de T3, levando ao aumento de marcação de $\mathrm{GH}$ na sua região perinuclear (sítio da maquinaria da tradução) e diminuição da marcação dela na periferia das células, sugerindo estímulo da secreção hormonal, além dos dados da literatura apontando para o eEF $1 \alpha$ como ancorador de transcritos ao citoesqueleto, o que por sua vez, aumenta ainda mais a estabilidade deles, o presente estudo teve como propósito, avaliar em ratos hipotiroideos submetidos ou não a tratamento agudo (30 $\min )$ com T3:

A) A taxa de tradução do mRNA do GH, por meio de análise do perfil polissomal, que nos fornece o quanto do transcrito está sendo recrutado pela maquinaria traducional.

B) O conteúdo de actina $\mathrm{F}$ (polimerizada) e $\mathrm{G}$ (não polimerizada) em hipófises, o que indicaria o grau de organização do seu citoesqueleto.

C) O conteúdo de eEF $1 \alpha$ ligado ao citoesqueleto, a partir do fracionamento de actina seguido de Western blotting,

D) O conteúdo de mRNA de GH ligado a actina F, por meio de real time PCR.

E) O conteúdo hepático de mRNA de IGF-1, por meio de real time PCR, dado indicativo do grau de secreção de GH. 


\section{MATERIAL E MÉTODOS}

\subsection{PROTOCOLO ANIMAL}

Foram utilizados ratos machos Wistar (Rattus norvegicus albinus), de 2 meses de idade, com peso em torno de 230-300 g, provenientes do biotério do Instituto de Ciências Biomédicas da USP, onde foram mantidos sob condições padronizadas de temperatura ambiental $\left(23 \pm 2^{\circ} \mathrm{C}\right)$ e ciclo claro/escuro (12/12 h diárias). A água e alimentação foram fornecidas ad libitum.

Parte dos animais foi submetida a tiroidectomia cirúrgica (Tx), sendo adicionados à água de beber metimazol $(0,03 \%)$ (inibidor de peroxidase tiroideana) e cloreto de cálcio $(0,05 \%)$, por um período aproximado de 20 dias (grupo hipotiroideo). Os animais Tx foram, ainda, divididos em grupos em que se administrou T3, conforme especificado abaixo. O grupo controle foi constituído de animais eutiroideos submetidos à cirurgia fictícia (falso operado - SO).

A divisão final dos grupos, de acordo com os tratamentos acima especificados foi a seguinte:

1. GRUPO EUTIROIDEO - (SO): animais submetidos à injeção endovenosa de salina e sacrificados após 30 min da mesma. (controle)

2. GRUPO HIPOTIROIDEO - (Tx): animais Tx tratados com salina e sacrificados após 30 min da injeção.

3. GRUPO T3 30 - (T3 $30 \mathrm{~min}$ ): animais Tx tratados com doses saturantes de T3 (100 $\mu \mathrm{g} / 100 \mathrm{~g}$ de peso corporal, ev) e sacrificados após $30 \mathrm{~min}$ da injeção.

4. *GRUPO T3 60 - (T3 60 min): animais Tx tratados com doses saturantes de T3 (100 $\mu \mathrm{g} / 100 \mathrm{~g}$ de peso corporal, ev) e sacrificados após 60 min da injeção. Esse grupo foi utilizado somente para estudo da expressão de IGF-1.

Após os períodos especificados, os animais foram sacrificados por decapitação. As hipófises foram removidas, para avaliação de diferentes parâmetros (abaixo relacionados), bem como o fígado, o qual foi utilizado para a determinação da expressão do mRNA do IGF-I, como 
parâmetro indicativo da secreção de GH. O sangue foi colhido do tronco e centrifugado; o soro foi estocado a $-20^{\circ} \mathrm{C}$ para posterior dosagem das concentrações de $\mathrm{T} 3$ por radioimunoensaio.

\subsection{PROTOCOLO EXPERIMENTAL}

\subsubsection{Perfil Polissomal e Northern blotting}

A análise do perfil polissomal tem como objetivo central determinar a parcela de um determinado mRNA (no caso, o mRNA do GH) que está sendo traduzida no momento estudado. Para o isolamento desta fração, utilizamos o procedimento descrito abaixo.

As hipófises foram removidas e homogeneizadas (baixa rotação) em tampão de extração, contendo: Tris- $\mathrm{HCl} 15 \mathrm{mM}$ pH 7.4, $\mathrm{MgCl}_{2} 15 \mathrm{mM}, \mathrm{NaCl} 300 \mathrm{mM}, 1 \%$ de Triton X-100, ciclohexamida $(1 \mathrm{mg} / \mathrm{ml})$, DTT-Dithiothreitol $0,33 \mathrm{mM}$ e heparina $1 \mathrm{mg} / \mathrm{ml}$, reconstituídos em $\mathrm{H}_{2} \mathrm{O}$ DEPC. Para cada grupo experimental foi utilizado um pool de 10 hipófises, que foram homogeneizadas em $600 \mu 1$, individualmente, ou seja, à medida que eram retiradas. Para preservação dos polissomos o extrato foi mantido todo o tempo no gelo. Após a coleta e homogeneização das hipófises, o extrato total foi centrifugado a $10.000 \mathrm{~g}$ por $10 \mathrm{~min}$ à $4^{\circ} \mathrm{C}$. O sobrenadante foi removido e transferido para outro eppendorf, devidamente identificado. $\mathrm{O}$ conteúdo de ácidos nucléicos do extrato total foi quantificado, em comprimento de onda de 260 $\mathrm{nm}$ e, em seguida, $14 \mathrm{U} / \mathrm{ml}$ (unidades de absorbância/ml) da amostra foram aplicadas no topo de um gradiente de sacarose (que se iniciou com 7\%, passando por 7.1\%, 7.2\% até $47 \%$ ) contendo: Tris- $\mathrm{HCl} 15 \mathrm{mM}$ pH 7.4, $\mathrm{MgCl}_{2} 15 \mathrm{mM}, \mathrm{NaCl} 300 \mathrm{mM}$, ciclohexamida (1mg/ml), DTTDithiothreitol $0,33 \mathrm{mM}$. O gradiente foi montado com auxílio de um aparelho específico (Biocomp - gradient master ip). Os tubos com as amostras foram balanceados, colocados no rotor SW41Ti (Beckman) e submetidos a ultracentrifugação a $39.000 \mathrm{rpm}$ por $2 \mathrm{~h}$ e $30 \mathrm{~min} \mathrm{a} 4^{\circ} \mathrm{C}$. Após a ultracentrifugação, as diferentes frações do gradiente foram coletadas em alíquotas de 900 $\mu$ l, a partir do topo, por meio de um coletor de frações (model 2110, Bio-Rad), acoplado a um detector de UV, em um comprimento de onda de $254 \mathrm{~nm}$, com auxílio de uma bomba peristáltica que injetava sacarose a $60 \%$ na base do tubo (que continha sacarose a 47\%). Com as frações obtidas, foram realizados ensaios de Northern blotting para detecção do mRNA do GH. 
As amostras coletadas do gradiente de sacarose (aproximadamente 0,9 $\mathrm{ml}$ ), foram descongeladas sob gelo, diluídas em $2 \mathrm{ml}$ de tiocianato de guanidina $4 \mathrm{M}$ e $3 \mathrm{ml}$ de etanol $100 \%$, e incubadas a $-20^{\circ} \mathrm{C}$ durante toda a noite. Os RNAs foram precipitados através de centrifugação a $10.000 \mathrm{~g}$, por $30 \mathrm{~min}$ a $4^{\circ} \mathrm{C}$; o sobrenadante foi desprezado e os pellets foram lavados com etanol $(75 \%)$ e mantidos a $4^{\circ} \mathrm{C}$ por 30 min. Cada pellet foi ressuspenso com $400 \mu \mathrm{lde} \mathrm{H}_{2} \mathrm{O}$ DEPC por agitação mecânica, aquecido a $65^{\circ} \mathrm{C}$ por 15 min e transferido para um eppendorf devidamente identificado, onde foi acrescentado $50 \mu \mathrm{l}$ de acetato de sódio $2 \mathrm{M} \mathrm{pH} 4 ; 1 \mathrm{ml}$ de etanol 100\% e 7,5 $\mu \mathrm{l}$ de heparina $(40 \mathrm{mg} / \mathrm{ml})$. Após centrifugação a $13.000 \mathrm{rpm}$ (Eppendorf model: 5415R) por 20 min a $4^{\circ} \mathrm{C}$, o sobrenadante foi desprezado e o pellet lavado com etanol $75 \%(500 \mu 1)$. As amostras contendo os RNAs foram centrifugadas a $10.000 \mathrm{~g}$ por $5 \mathrm{~min}$ a $4^{\circ} \mathrm{C}$, secadas por aproximadamente $6 \mathrm{~min}$ em speed-vac e submetidas à eletroforese e ensaios de Northern blotting para detecção do mRNA do GH.

O RNA das duas primeiras amostras do perfil polissomal foi extraído utilizando-se o método guanidina-fenol-clorofórmio (CHOMCZYNSKI e SACCHI, 1987). O motivo para a escolha de outra metodologia foi a grande concentração de proteínas presentes nestas frações. Essas proteínas formam um precipitado muito espesso, após a centrifugação, que não é dissolvido durante a extração, inviabilizando o seu uso para esse fim. Convém ressaltar a importância dessas duas amostras, já que se trata da fração de RNA livre, ou seja, da que não está ligada as sub-unidades ribossomais, ribossomos ou polissomos.

As amostras foram transferidas para um tubo, onde se iniciou a extração do RNA por solução 2 M de acetato de sódio, pH 4,0, fenol saturado em água e clorofórmio/álcool isoamílico (49:1 vol/vol). Seguiu-se incubação por 15 min no gelo e a centrifugação a 10.000 g, por 20 min a $4^{\circ} \mathrm{C}$.

No final da centrifugação visualizam-se 3 fases distintas. A fase aquosa, contendo o RNA, foi aspirada cuidadosamente e transferida para outro tubo, onde se adicionou 1 volume de isopropanol a $-20^{\circ} \mathrm{C}$. Após incubação por aproximadamente 1 hora, à $-20^{\circ} \mathrm{C}$ (fase em que se favorece a precipitação do RNA) seguiu-se uma centrifugação a $10.000 \mathrm{~g}$ por $20 \mathrm{~min}$ a $4^{\circ} \mathrm{C}$, sendo o sobrenadante desprezado e o pellet (RNA) dissolvido em solução D (4M de tiocianato de guanidina, $25 \mathrm{mM}$ de citrato de sódio, $\mathrm{pH} 7.0,0,5 \%$ N-lauril sariosini e $0,1 \mathrm{M}$ de $\beta$ mercaptoetanol) e precipitado com um volume de isopropanol a $-20^{\circ} \mathrm{C}$, (incubação por 1 hora ou 
overnight a $-20^{\circ} \mathrm{C}$ ). $\mathrm{O}$ tubo foi, novamente, centrifugado por $10 \mathrm{~min}$, a $10.000 \mathrm{~g}$, a $4^{\circ} \mathrm{C}$ e o sobrenadante desprezado, sendo o pellet ressuspenso com etanol $75 \%\left(-20^{\circ} \mathrm{C}\right)$, para remoção das impurezas. Após incubação por 15 min à temperatura ambiente, seguiu-se nova centrifugação a $10.000 \mathrm{~g} \mathrm{a} 4^{\circ} \mathrm{C}$ por $5 \mathrm{~min}$ e, novamente, o sobrenadante foi descartado. $\mathrm{O}$ pellet, que representa o RNA obtido, foi submetido à liofilização no Speed-Vac, por $10 \mathrm{~min}$, sendo a seguir dissolvido em $\mathrm{H}_{2} \mathrm{O}$ DEPC (20 a $50 \mu \mathrm{l}$ ), em banho-maria, por $5 \mathrm{~min}$ a $65^{\circ} \mathrm{C}$ e estocado a $-80^{\circ} \mathrm{C}$ para uso futuro.

Para identificação do mRNA do GH, os RNAs foram separados por eletroforese em gel de agarose $(1 \%) /$ formaldeído, realizada em uma cuba horizontal $(12 \times 24 \mathrm{~cm})$, utilizando um tampão de corrida contendo 1X MOPS (40 mM de ácido morfolinopropanosulfônico, pH 7,0; 10 mM de acetato de sódio e $1 \mathrm{mM}$ de EDTA, pH 8,0). A agarose (1\%) foi solubilizada em solução de $1 \mathrm{X}$ MOPS fervente (micro-ondas por $5 \mathrm{~min}$ ), aguardando-se o esfriamento da solução até aproximadamente $60^{\circ} \mathrm{C}$, para adição do formaldeído (37\%). O RNA total de cada amostra foi, então, submetido a desnaturação por solução contendo formaldeído (17,5\% vol/vol), formamida deionizada (50\% vol/vol), 10X MOPS (5\% vol/vol) e H2O DEPC, sob aquecimento $\left(65^{\circ} \mathrm{C}\right)$. A solução de blue-juice recém-preparada (50\% glicerol, 1 mM EDTA, 0,4\% de azul de bromofenol) foi acrescentada às amostras, as quais foram, em seguida, aplicadas no gel de agarose, anteriormente imerso no tampão de corrida (1X MOPS). Seguiu-se a eletroforese das amostras sob uma diferença de potencial constante de aproximadamente $70 \mathrm{~V}$, por cerca de 3,5 h. Após a eletroforese, os RNAs ribossômicos foram visualizados, através da coloração do gel com solução contendo brometo de etídio $(0,5 \mu \mathrm{g} / \mathrm{ml})$, o qual emite fluorescência quando submetido à luz ultravioleta. Este procedimento permitiu verificar se as faixas do gel estavam carregadas com as mesmas quantidades de RNA, sendo possível então a comparação entre as amostras. Além disto, foi avaliada a integridade do RNA, por meio da visualização de bandas bem definidas dos RNA ribossomais $28 \mathrm{~S}$ e $18 \mathrm{~S}$ (CHIN et al., 1998). Como controle adicional da quantidade de RNA total depositada no gel, as membranas foram hibridadas com a sonda ${ }^{32} \mathrm{P}$ c-rRNA específica contra o RNA ribossomal 18S, conforme será descrito.

Para realização do Northern blotting, o RNA fracionado pela eletroforese foi transferido para uma membrana de nylon, por capilaridade, empregando a técnica descrita por Thomas, modificada por Maniatis et al. (1989). O sistema foi composto de um recipiente de vidro (pirex) contendo uma solução de 10X SSC (1,5 M NaCl; 0,15 M citrato de sódio, pH 7,0). Uma esponja 
foi colocada dentro do pirex, absorvendo a solução de SSC 10X; sobre a esponja foi colocada uma folha de papel 3M e sobre esta, foi colocado o gel (posição invertida). O gel foi coberto por uma membrana de nylon, que identificava com um corte a seqüência de amostras de RNA depositadas; as bordas foram vedadas com parafilm e foram colocadas sobre a membrana: uma folha de papel 3M (de mesma área do gel), uma segunda esponja de dimensões semelhantes à do gel e uma base de vidro sobre a qual um peso de cerca de $250 \mathrm{~g}$ foi colocado. Por capilaridade, a solução SSC ascende pelas esponjas e papel 3M em direção à segunda esponja; este fluxo faz com que as moléculas de RNA contidas no gel de agarose sejam vagarosamente conduzidas até a membrana onde ficam imobilizadas. Após a transferência $(12-14$ h), a membrana foi cuidadosamente retirada, lavada em solução de 6X SSC e deixada por 30 minutos em temperatura ambiente; em seguida, a membrana foi secada em forno à vácuo, a $80^{\circ} \mathrm{C}$ por, no mínimo, uma hora para fixação do RNA. Após a fixação, a membrana foi colocada em solução de ácido acético 5\% por 15 min e corada com azul de metileno, ambos dissolvidos em água DEPC, por no mínimo 3 min, quando se tornaram visíveis as bandas dos RNAs ribossômicos (CHIN et al., 1998). O excesso de corante foi retirado, lavando-se a membrana por 15 minutos em água DEPC. Após a lavagem, a membrana foi submetida à pré-hibridação e a hibridação.

A sonda do GH foi marcada com ${ }^{32} \mathrm{P}-\mathrm{dCTP}$, por random priming, utilizando-se o kit comercial Random Primer DNA Labeling System (GIBCO-BRL).

A membrana de nylon foi lavada em solução 2X SSC e 1\% SDS por 15 min e umedecida em 6X SSC e, em seguida, ela foi incubada em líquido de pré-hibridação, contendo $50 \%$ formamida, 2\% SDS, $1 \%$ BSA, 5X reagente de Denhardt's, $100 \mu \mathrm{g} / \mathrm{ml}$ de DNA de esperma de salmão (GIBCO-BRL) e 6X SSC, por 4 horas a $42^{\circ} \mathrm{C}$ em forno de hibridação (AMERSHAM PHARMACIA). Após este período, adicionou se a sonda com atividade específica de $3.0 \times 10^{5}$ c.p.m. para cada $\mathrm{ml}$ de líquido de pré-hibridação, dando-se início a hibridação, que foi realizada em aproximadamente $15 \mathrm{~h}$. A membrana foi, então, lavada por 15 min em SSC (de 2 a $0,1 \mathrm{X}$ ) e SDS (de 0,1 a $1 \%$ ) três vezes, e 30 minutos em 1 X SSC e $1 \%$ SDS a $50^{\circ}$ C. Após a lavagem, a membrana foi colocada em chassis contendo um filme, que foi sensibilizado por aproximadamente $48 \mathrm{~h}$ e depois revelado e fixado dentro de uma sala escura. A densitometria das bandas foi realizada com o auxílio do programa Image Master-1D-Pharmacia Biotech, SW.

A marcação da sonda para RNAr 18S foi realizada com o Kit Maxi Script ${ }^{\mathrm{TM}}$ T3/T7 - In vitro RNA transcription kits (AMBION), seguindo o protocolo do fabricante. Para esta reação 
utilizou se $1 \mu \mathrm{g}$ do plasmídeo pTRI RNA $18 \mathrm{~S}$ (AMBION), que contém um inserto, em orientação antisense, de $80 \mathrm{pb}$ de uma região altamente conservada do gene do RNAr humano, de modo que as sondas de RNA transcritas desse molde são complementares ao RNAr 18S. Seguiu se a adição de 5X tampão de transcrição, 10 mM ATP, 10 mM CTP, 10 mM GTP, 12,5 mM ${ }^{32}$ P-dUTP (3000 Ci/mmol - Amersham), T7 RNA polimerase e inibidor de ribonuclease. A reação foi incubada a $37^{\circ} \mathrm{C}$ por $1 \mathrm{~h}$. Em seguida foi adicionado à mistura DNAse I (2 U/ $\left.\mu \mathrm{l}\right)$, livre de RNAse, para que a fita molde de DNA fosse destruída, restando assim apenas a fita de RNA recém-sintetizada; essa reação ocorreu por 15 min a $37^{\circ} \mathrm{C}$ e foi interrompida adicionando-se $0,5 \mathrm{M}$ de EDTA. A sonda foi, então, purificada através da coluna spin columm-100 (SIGMA), tratada com $\mathrm{H}_{2} \mathrm{O}$ DEPC. Utilizamos 3,0 X $10^{5} \mathrm{cpm}$ da sonda para cada ml de líquido de pré-hibridação.

Como as membranas já tinham sido utilizadas para marcar o mRNA do GH, elas foram submetidas a stripping em solução contendo SDS e água DEPC por 15 min à temperatura de $100^{\circ}$ C. A hibridação da sonda da $18 \mathrm{~S}$ ribissomal foi realizada, a seguir, a $42^{\circ} \mathrm{C}$ overnight. Após a hidridação, as membranas foram lavadas nas mesmas condições descritas para a sonda do GH. No final das lavagens, as membranas foram expostas e sensibilizadas por mais ou menos 1 hora, seguidas de revelação para detecção do sinal radiográfico (bandas) e fixação do sinal no filme. A intensidade das bandas, que representa o conteúdo de $18 \mathrm{~S}$, foi analisada pelo programa Image Master-1D-Pharmacia Biotech, SW e expresso em unidades arbitrárias (U.A.), unidades estas que foram utilizadas para normalizar o contéudo de mRNA do GH.

\subsubsection{Avaliação da expressão da Actina Polimerizada (actina F) e Não Polimerizada (actina G)}

Este protocolo foi uma readapatação feita a partir de Haller (2004), que por sua vez, adaptou de Posern et al, (2002), para demonstrar o papel do citoesqueleto na distribuição de proteínas no intracelular. Os animais foram decapitados, as hipófises foram removidas (pool de 2 hipófises por $\mathrm{N}$ ), homogeneizadas em um tampão adequado, contendo: $50 \mathrm{mM}$ de $\mathrm{NaCl}, 1 \mathrm{mM}$ de EDTA, 0,5\% de Triton X-100 e 20 mM de HEPES, pH 7.9, em um volume de $400 \mu 1$. Nesse tampão foi colocado faloidina, um estabilizador de microfilamentos, com o intuito de preservar a actina polimerizada. A concentração de faloidina utilizada foi de $132 \mathrm{nM}$. O homogeneizado foi mantido no gelo por 10 min e, então, submetido a ultracentrifugação a 100.000 g por 30 min a $4^{\circ}$ C (Beckman). Ao final da ultracentrifugação, o sobrenadante foi separado, colocado em outro 
eppendorf devidamente identificado e congelado $\left(-80^{\circ} \mathrm{C}\right)$ até o dia da quantificação da proteína. O pellet foi ressuspenso com $100 \mu$ do tampão de homogeneização (sem faloidina) e lisado por sonicação (Sonics \& Materials Inc). A solução resultante foi transferida para um eppendorf e congelada $\left(-80^{\circ} \mathrm{C}\right)$ até o dia da quantificação da proteína. A quantificação foi feita pelo método de Bradford (1976) e $40 \mu \mathrm{g}$ de proteínas, tanto do sobrenadante como da solução em que o pellet foi dissolvido, foram aliquotadas, liofilizadas e submetidas ao SDS-PAGE.

As proteínas liofilizadas foram reconstituídas em tampão de Lammeli 1X (loading buffer2X), Tris-EDTA pH 7.5 e $200 \mathrm{mM}$ de DTT. As amostras foram aquecidas a $100^{\circ} \mathrm{C}$ por $10 \mathrm{~min}$, agitadas por vórtex e precipitadas em microcentrífuga (1 pulso).

As amostras foram aplicadas em gel de poliacrilamida $10 \%$ e a eletroforese realizada a uma voltagem constante de 100V por, aproximadamente, 3 horas, em tampão específico ( $25 \mathrm{mM}$ de Tris, $192 \mathrm{mM}$ de glicina e $0,1 \%$ de SDS). Uma amostra padrão com pesos moleculares conhecidos $(220 ; 160 ; 120 ; 100 ; 90 ; 80 ; 70 ; 60 ; 50 ; 40 ; 30 ; 25 ; 20 ; 15$ e $10 \mathrm{kDa})$ foi depositada em uma das janelas do gel para estimar a localização da banda correspondente da proteína de interesse.

Após a eletroforese, as proteínas presentes no gel de poliacrilamida foram transferidas para uma membrana de nitrocelulose sob voltagem de $100 \mathrm{~V}$ por $1 \mathrm{~h}$ (sistema Bio Rad) em tampão específico e $20 \%$ de álcool metílico (TOWBIN et al., 1979). A cuba de transferência foi mantida dentro de um recipiente contendo gelo para impedir a elevação da temperatura da cuba. Ao final da transferência, a membrana foi corada com Ponceau (para confirmar a transferência das proteínas do gel para membrana) e lavada com água destilada para remover o excesso do corante.

A membrana foi bloqueada com leite desnatado (5\%) em PBST (Tampão fosfato salina adicionado de $0,1 \%$ de Tween 20) à temperatura ambiente, por 1 h. Após bloqueio, a membrana foi incubada com anticorpo específico contra actina (anti $\beta$ actina - Sigma), gerado em camundongo, diluído na solução de bloqueio e mantido em uma concentração de 1:5000. Ao final da incubação com anticorpo primário, as membranas foram lavadas três vezes por 10 min em temperatura ambiente com PBST, incubadas com anticorpo secundário (anti-camundongo, conjugado com peroxidase) por $1 \mathrm{~h}$ à temperatura ambiente e lavadas três vezes, por $10 \mathrm{~min}$, à 
temperatura ambiente com PBST. As membranas foram tratadas com reagentes quimioluminescentes (ECL-Amershan), onde volumes iguais das soluções de ECL foram misturados, e incubados por $1 \mathrm{~min}$. O reagente foi aplicado sobre a membrana por $3 \mathrm{~min}$, no escuro; o excesso foi retirado e a membrana exposta a um filme autorradiográfico, cuja análise densitométrica foi realizada por meio do software Image Master- 1D (Pharmacia Biotech, SW).

\subsubsection{Ensaio para avaliação da taxa de ligação do eEF $1 \alpha$ com o citoesqueleto}

A quantidade de EF $1 \alpha$ foi determinada tanto na fração correspondente à actina $F$ quanto na de actina $\mathrm{G}$, sendo assim, o método usado para investigar a ligação entre o EF $1 \alpha$ e citoesqueleto foi o mesmo para separar a actina $F$ (precipitado) da actina $G$ (sobrenadante).

A parte inicial de extração não sofreu nenhuma alteração, permanecendo igual ao descrito acima. Após a ultracentrifugação, as proteínas do precipitado, assim como do sobrenadante, foram quantificadas pelo método de Bradford e $40 \mu \mathrm{g}$ foram aplicadas em gel de poliacrilamida 10\%. A eletroforese foi seguida de eletrotransferência, bloqueio da membrana com leite desnatado e incubação com anti- EF $1 \alpha$ (1:1000), produzido em camundongo. Um anticorpo anti-mouse conjugado com peroxidase (anticorpo secundário) foi utilizado e o sinal obtido foi identificado por ECL. Todos os detalhes do experimento, como tampões utilizados, tempo das reações e o processamento das imagens, são semelhantes aos descritos para actina, apresentados acima.

2.2.4 Ensaio para avaliar o conteúdo do mRNA de GH ligado ao citoesqueleto

Os animais foram decapitados, as hipófises foram removidas (pool de 3 hipófises por N), homogeneizadas em um tampão adequado, contendo: $50 \mathrm{mM}$ de $\mathrm{NaCl}, 1 \mathrm{mM}$ de EDTA, 0,5\% de Triton X-100 e 20 mM de HEPES, pH 7.9, em um volume de $400 \mu$ l. Nesse tampão foi colocado faloidina, um estabilizador de microfilamentos, com o intuito de preservar a actina polimerizada. A concentração de faloidina utilizada foi de $132 \mathrm{nM}$. O homogeneizado foi mantido no gelo por 10 min e, então, submetido a ultracentrifugação a $100.000 \mathrm{~g}$ por $30 \mathrm{~min}$ a $4^{\circ} \mathrm{C}$ (Beckman). Ao final da ultracentrifugação, o sobrenadante foi desprezado e o precipitado ressuspenso com 100 
$\mu 1$ do tampão de homogeneização (sem faloidina), lisado por sonicação (Sonics \& Materials inc) e transferido para outro eppendorf devidamente identificado.

O RNA total foi extraído do precipitado pelo método de guanidina-fenol-clorofórmio. As amostras foram transferidas para um tubo, onde se iniciou a extração do RNA por guanidina 4 M, solução 2 M de acetato de sódio, pH 4,0, fenol saturado em água e clorofórmio/álcool isoamílico (49:1 vol/vol). Seguiu-se incubação por 15 minutos no gelo e a centrifugação a $10.000 \mathrm{~g}$, por 20 minutos a $4^{\circ} \mathrm{C}$.

No final da centrifugação visualizam-se 3 fases distintas. A fase aquosa, contendo o RNA, foi aspirada cuidadosamente e transferida para outro tubo, onde se adicionou 1 volume de isopropanol a $-20^{\circ} \mathrm{C}$. Após incubação por aproximadamente 1 hora, à $-20^{\circ} \mathrm{C}$ (fase em que se favorece a precipitação do RNA) seguiu-se a centrifugação a $10.000 \mathrm{~g}$ por $20 \mathrm{~min}$ a $4^{\circ} \mathrm{C}$, sendo o sobrenadante desprezado e o pellet (RNA) dissolvido em solução D e precipitado com um volume de isopropanol a $-20^{\circ} \mathrm{C}$, (incubação por uma hora ou overnight a $-20^{\circ} \mathrm{C}$ ). $\mathrm{O}$ tubo foi, novamente, centrifugado por $10 \mathrm{~min}$, a $10.000 \mathrm{~g}$, a $4^{\circ} \mathrm{C}$ e o sobrenadante desprezado, sendo o pellet ressuspenso com etanol $75 \%\left(-20^{\circ} \mathrm{C}\right)$, para remoção das impurezas. Após incubação por 15 min à temperatura ambiente, seguiu-se nova centrifugação a $10.000 \mathrm{~g}$ a $4^{\circ} \mathrm{C}$ por 5 min e novamente o sobrenadante foi descartado. O pellet, que representa o RNA obtido, foi liofilizado no Speed-Vac, ressuspendido em $\mathrm{H}_{2} \mathrm{O}$ DEPC $(50 \mu \mathrm{l})$ e dissolvido por aquecimento a $65^{\circ} \mathrm{C}$ por 15 min (CHOMCZYNSKY e SACCHI, 1987). O RNA total foi quantificado em espectrofotômetro, usando comprimento de onda de $260 \mathrm{nM}$. A integridade do RNA foi confirmada pela verificação, por eletroforese, do padrão de bandas do RNA ribossomal $28 \mathrm{~S}$ e $18 \mathrm{~S}$ em gel de agarose $1 \%$, visualizado em luz ultravioleta.

As amostras de RNA foram tratadas com DNAses (RNase free DNase I - Invitrogen NZ Ltd, Auckland, New Zealand), antes do Real Time-PCR (RT-PCR), para eliminar qualquer resíduo de DNA genômico. Foram usados $2 \mu \mathrm{g}$ do RNA total para a reação, adicionando-se: oligo dT $(100 \mu \mathrm{g} / \mathrm{mL}), 10 \mathrm{mM}$ de cada dNTP, 5X First-Strand buffer e $2 \mu \mathrm{l}$ de enzima (200 U/ $\mu \mathrm{l})$ M-MLV Reverse Transcriptase (Promega). A reação de transcrição reversa foi realizada num ciclo de $65^{\circ} \mathrm{C}$ por $10 \mathrm{~min}$, seguido por $37^{\circ} \mathrm{C}$ por $60 \mathrm{~min}$ e $10 \mathrm{~min}$ a $95^{\circ} \mathrm{C}$. 
A técnica utilizada para estimar a abundância dos valores relativos de mRNA de GH em animais controle e hipotiroideos tratados com salina e T3 foi baseada na detecção em tempo real do produto do PCR pela quantificação de fluorescência avaliada pelo detector de seqüência ABI Prism 7700 (Applied Biosystems, Foster City, CA, USA), baseado na metodologia corrente. As amplificações do RT-PCR foram executadas com $2 \mu 1$ do produto da reação de transcrição reversa diluídos em um tampão de reação contendo: $5 \mu 1$ SYBR @ Green PCR master mix, $900 \mathrm{nM}$ primers (sense e anti-sense para GH ou Ciclofilina, que foi utilizado como controle interno da reação). Todos os primers usados foram otimizados para análise por Real time RT-PCR (temperatura de anelamento para todos os primers: $58^{\circ} \mathrm{C}$ ) e estão listados abaixo. Os ciclos consistiram de duas fases: uma a $50^{\circ} \mathrm{C}$ por 2 min (ativação da enzima) e outra a $95^{\circ} \mathrm{C}$ por 10 min (desnaturação), seguidas por 45 ciclos de três fases: a primeira a $95^{\circ} \mathrm{C}$, por $20 \mathrm{seg}$ (desnaturação), a segunda a $58^{\circ} \mathrm{C}$, por $30 \mathrm{seg}$ (anelamento) e a terceira a $72^{\circ} \mathrm{C}$, por $30 \mathrm{seg}$ (extensão).

O ponto inicial do ciclo (CT) do real-time RT-PCR foi avaliado em triplicata para cada amostra. Os valores de CT correspondem ao número do ciclo do PCR e representam a intensidade da fluorescência emitida pelo produto do RT-PCR amplificado do gene alvo e são inversamente proporcionais ao conteúdo de mRNA da amostra. O valor da variação de $\mathrm{CT}(\Delta \mathrm{CT})$ foi calculado subtraindo-se o valor do CT do gene de interesse $(\mathrm{GH})$ do valor do CT do gene usado como referência (Ciclofilina). Para se reduzir as variações entre as amostras, todas elas foram normalizadas pela média da variação do valor de CT $(\Delta \mathrm{CT})$ dos animais controle, originando um valor chamado de $\Delta \Delta \mathrm{CT}$. A expressão relativa do $\mathrm{GH}$ foi calculada usando-se a expressão $2^{-\Delta \Delta C T}$ e é representada em unidades arbitrárias (LIVAK e SCHMITTGEN, 2001). 
Primers usados no RT-PCR

\begin{tabular}{|c|c|}
\hline Primers & Sequence \\
\hline Sense: $\mathbf{G H}$ & 5'- TCAAGAAGGACCTGCACAAG-3' \\
\hline Antisense: GH & 5'- GTGGCAGTTGCCAGAGTACA-3' \\
\hline Sense: Ciclofilina & 5'- GGATTCATGTGCCAGGGTGG -3' \\
\hline Antisense: Ciclofilina & 5'- CACATGCTTGCCATCCAGCC -3' \\
\hline
\end{tabular}

\subsubsection{Avaliação do conteúdo hepático do mRNA de IGF-1}

A extração de RNA do fígado foi realizada de acordo com o método guanidina-fenolclorofórmio, como descrito acima para o GH das primeiras frações do perfil polissomal. No final da extração as amostras foram submetidas à reações de transcrição reversa (reverse transcriptase) e real time PCR para IGF-1. A metodologia de RT-PCR e real time PCR usada para o IGF-1 foi a mesma utilizada para determinação da expressão do mRNA GH.

\begin{tabular}{|c|c|}
\hline Primers & Sequence \\
\hline Sense : IGF1 & 5'-AGGCCTACAAAGTCAGCTCG -3' \\
\hline Antisense: IGF1 & 5'- GGTCTTGTTTCCTGCACTTC -3' \\
\hline Sense: Ciclofilina & 5'- GGATTCATGTGCCAGGGTGG -3' \\
\hline Antisense: Ciclofilina & 5'- CACATGCTTGCCATCCAGCC -3' \\
\hline
\end{tabular}




\subsubsection{Análise Estatística}

Os resultados foram expressos como média \pm erro padrão da média (SEM), dos valores obtidos por densitometria dos auto-radiogramas das bandas (northern e western blot) ou pelos valores de CT, quando a análise se referiu ao RT-PCR . Os resultados foram avaliados por meio de análise de variância (ANOVA), seguida do pós teste de Student-Newman-Keuls, ou o teste T não pariado (unpaired t test), conforme indicado. Os dados foram considerados significativos para valores de $\mathrm{p}<0.05$. 


\section{RESULTADOS}

Confirmação dos estados eutiroideos e hipotiroideos por meio de parâmetros funcionais.

Os parâmetros funcionais utilizados para determinar o estado hipotiroideo (Tx) dos animais foram o peso corporal, o peso do coração (úmido e seco), a razão entre peso ventricular e peso corporal, além da dosagem de T3 no soro dos animais.

No dia da cirurgia os animais estavam com peso médio de \pm 250 g e, após 20 dias de tiroidectomia, apresentaram queda de peso (média: $\pm 223 \mathrm{~g}$ ). Já os animais eutiroideos, que são os nossos controles, apresentaram um ganho de massa, com peso médio de $\pm 294 \mathrm{~g}$. Essa queda de peso, vista nos animais Tx, pode ser justificada pela diminuição da síntese e secreção de GH observada no hipotiroidismo, o que por sua vez, leva a uma menor síntese protéica e, consequentemente, perda de massa magra.

Outro parâmetro utilizado foi o peso do coração. O coração foi pesado logo após o sacríficio dos animais e colocado na estufa à $37^{\circ} \mathrm{C}$ por 48 horas para desidratar. No final das 48 horas o coração seco (desidratado) foi pesado e os valores obtidos anotados e utilizados como indicadores da quantidade de proteína no tecido cardíaco. A análise do coração aponta para uma redução de peso vista antes e após a desidratação do tecido nos animais hipotiroideos, em relação ao grupo controle, o que indica uma menor síntese protéica, ao invés de um excesso de água (MOHR-KAHALY et al., 1996; POLIKAR et al., 1993).

A relação entre o peso ventricular (PV) e o peso corporal (PC) foi calculada, gerando uma razão que nos permitiu avaliar o ganho de massa cardíaca sobre o peso dos animais (GIANNOCCO et al., 2004). Os animais Tx tratados agudamente com salina ou T3, ao serem comparados com o animais eutiroideos, apresentaram uma redução da massa cardíaca concomitante a uma diminuição do peso corporal. Esses resultados fortalecem os dados obtidos para hipotrofia cardíaca com o peso úmido e seco dos corações desses animais. 
A concentração sérica de T3 foi determinada por radioimunoensaio, utilizando-se o Kit comercial RIA-gnost T3 (CIS bio international) adquirido da REM, com exceção da curva padrão do Kit que foi substituída por uma construída a partir da adição de concentrações conhecidas de T3 $(0.0 ; 0.125 ; 0.250 ; 0.500 ; 1.00 ; 2.00$ e $4.00 \mathrm{ng})$ ao soro de ratos depletado de HTs, o que ocorreu por meio de uma resina específica para esse fim (AG-1X8 - Bio Rad). 
Tabela 01: Avaliação hipotiroideo tratado por $30 \mathrm{~min}$ com T3 (T3 30). Foram realizados sete experimentos, cada um deles com $\mathrm{N}=5$.

Valores estão expressos em média \pm erro dos parâmetros funcionais dos animais do grupo eutiroideo (SO), hipotiroideo (Tx) e médio padrão.

$* \mathrm{p}<0.001$ vs SO.

$\# \mathrm{p}<0.0001$ vs SO. Os dados referentes à concentração de T3 do soro dos animais Tx tratados com T3 não foram incluídos na análise estatística.

\begin{tabular}{c|c|c|c|c|c}
\hline Grupos & Peso & $\begin{array}{c}\text { Ventrículo } \\
\text { Peso úmido }\end{array}$ & $\begin{array}{c}\text { Ventrículo } \\
\text { Peso seco }\end{array}$ & PV/PC & $\begin{array}{c}\text { T3 sérico } \\
\text { (ng/ml) }\end{array}$ \\
\hline SO & $294 \pm 5.28$ & $0.92 \pm 0.01$ & $0.23 \pm 0.004$ & $0.32 \pm 0006$ & $0.357 \pm 0.008$ \\
\hline Tx & $223 \pm 4.31^{*}$ & $0.60 \pm 0.02^{*}$ & $0.15 \pm 0.003^{*}$ & $0.25 \pm 0009^{*}$ & $0068 \pm 0.008 \#$ \\
\hline T3 30 min & $223 \pm 4.31^{*}$ & $0.54 \pm 0.02^{*}$ & $0.14 \pm 0.005^{*}$ & $0.25 \pm 0007^{*}$ & $>10$ \\
\hline
\end{tabular}


3.1 Análise do Perfil Polissomal hipofisário (detecção do mRNA do GH) de ratos eu, hipo e hipotiroideos tratados agudamente com T3.

Por meio da avaliação da absorbância das amostras obtidas a partir do procedimento descrito em Material e Métodos, foram obtidos registros de vários picos correspondentes às diferentes frações de RNAs presentes nas mesmas.

Os primeiros picos correspondem às sub-unidades 40S e 60S do RNA, sendo que a subunidade $60 \mathrm{~S}$ é representada por um pico que é maior que o da $40 \mathrm{~S}$ e até mesmo, maior que o pico da unidade ribossomal $80 \mathrm{~S}$, que vem a seguir. Este é muito pequeno, característica que tem se preservado ao longo dos perfis realizados. Os picos que se seguem ao da $80 \mathrm{~S}$ representam a porção polissomal, sendo que, quanto mais distante os picos estiverem da $80 \mathrm{~S}$, mais ribossomos estão ligados ao mRNA.

No perfil polissomal obtido a partir de hipófises dos animais eutiroideos, o conteúdo de mRNA de GH foi detectado, em sua maioria, nos polissomos (Fig 01A). A análise do filme superexposto, revelou também a presença de mRNA de GH nas outras frações do perfil, que não são polissomais (dados não mostrados). Esse dado sugere que a maioria dos transcritos de GH produzidos é recrutada para a maquinaria traducional, a qual é responsável pela geração de proteínas.

Já, os animais hipotiroideos (Tx) tratados com salina por 30 min apresentam uma redução acentuada da expressão gênica de GH. No entanto, todo o mRNA de GH parece ter sido direcionado para a maquinaria traducional, pois pela análise do perfil polissomal esse mRNA aparece somente nos polissomos (Fig 01B).

Quando os animais hipotiroideos foram tratados com T3, por $30 \mathrm{~min}$, o conteúdo de mRNA de GH aumentou, o que já era esperado pela análise do RNA total hipofisário realizada em trabalhos prévios do laboratório (VOLPATO et al, 2000). No entanto, esse aumento de mRNA de GH foi detectado somente na fração polissomal, evento sugestivo de que o tratamento promoveu recrutamento do transcrito para o processo de tradução (Fig 01C). 


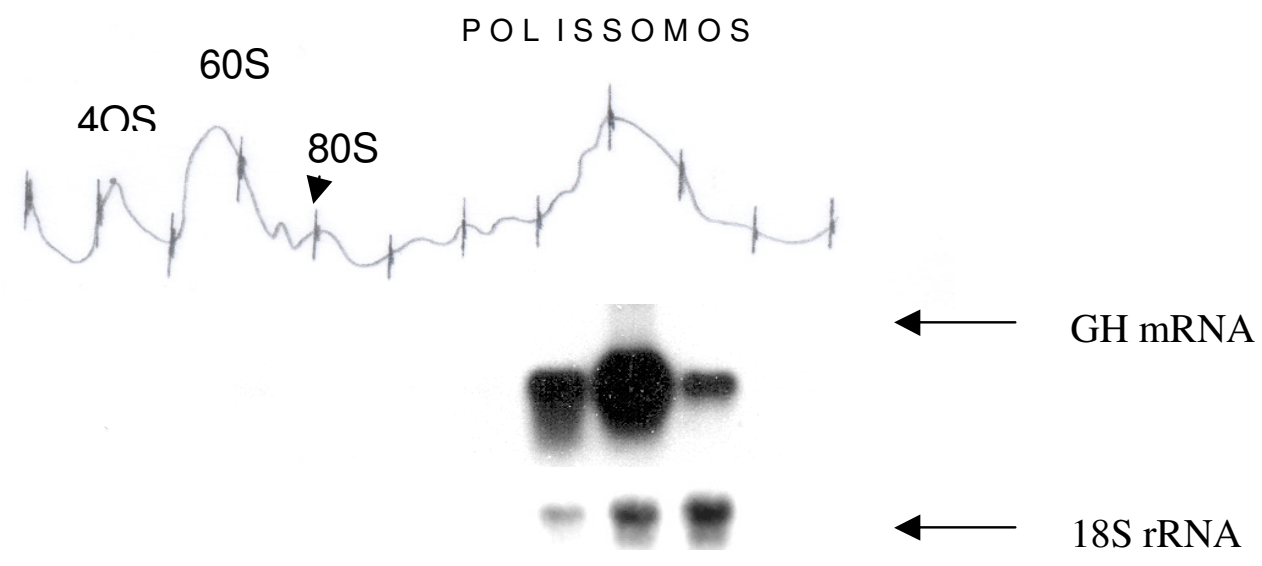

A

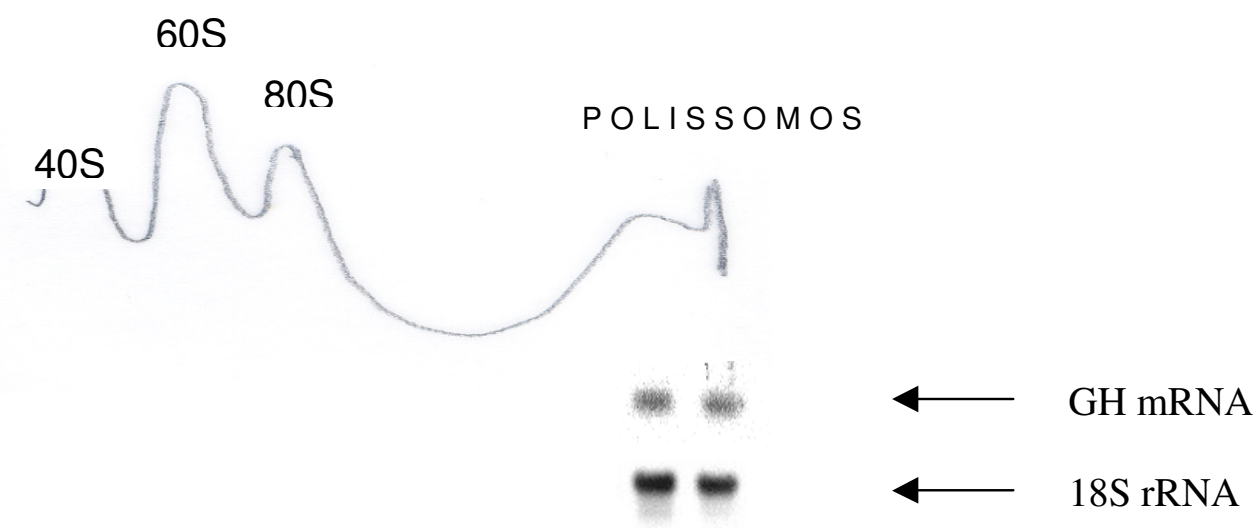

B

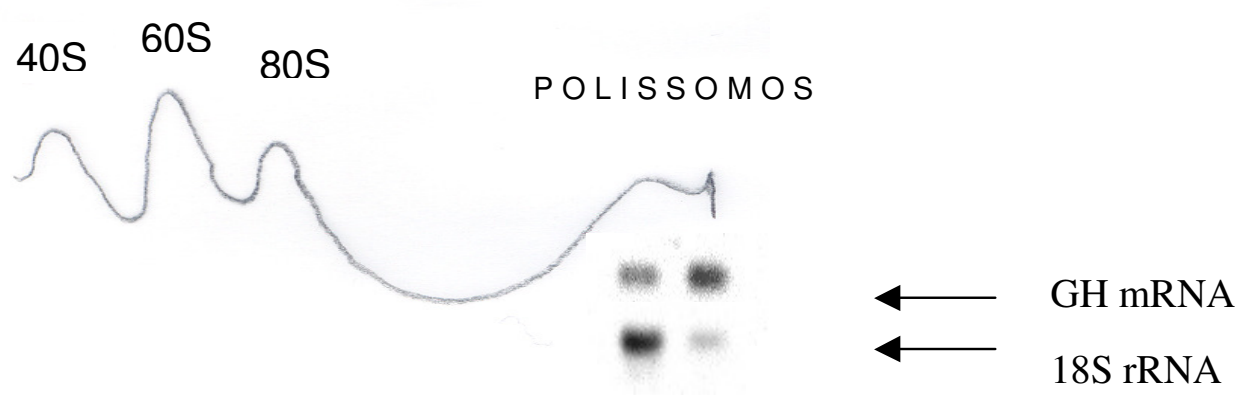

Figura 01: Análise do Perfil Polissomal de hipófises de ratos eutiroideos- SO (A) e hipotiroideos tratados com salina- Tx (B) ou T3 por 30 min- T3 $30 \mathrm{~min}$ (C). O RNA total foi extraído das frações do perfil polissomal e submetido à hibridação com sonda radioativa para mRNA de GH. Um pool de 10 hipófises foi utilizado para cada extrato. As sub-unidades ribossomais $40 \mathrm{~S}$ e $60 \mathrm{~S}$ estão representadas no perfil polissomal, seguidas pela $80 \mathrm{~S}$ e polissomos, conforme ilustram os gráficos apresentados nas partes superiores da figura $1(\mathrm{~A}, \mathrm{~B}, \mathrm{C})$. O sinal radiográfico representativo do mRNA de GH está posicionado logo abaixo da fração polissomal, e o da banda da 18S rRNA abaixo desta. 
3. 2 Efeito do T3 sobre o remodelamento da actina: Análise do conteúdo hipofisário de actina polimerizada (actina F) e não polimerizada (actina $G$ ).

A técnica de fracionamento de actina consiste em separar a actina polimerizada (F-actina) da não polimerizada, encontradas no precipitado e sobrenadante, respectivamente. A actina polimerizada é preservada pela adição de faloidina ao tampão de lise, uma toxina capaz de se ligar somente a F-actina (HALLER et al, 2004).

Utilizamos esse método, realizando poucas modificações, inicialmente para avaliar o conteúdo de actina polimerizada em hipófise de animais eutiroideos (SO) e Tx, antes e após o tratamento com T3, conforme ilustra a Fig 02, e, posteriormente, para a avaliação da associação entre outras proteínas e transcritos com o citoesqueleto, como será mostrado adiante nas figuras 03 e 04 , respectivamente.

A análise do fracionamento de actina das hipófises dos animais hipotiroideos tratados com salina revelou diminuição do contéudo de actina na fração insolúvel (precipitado) (Fig 02 A), e aumento dela na fração solúvel (sobrenadante), (Fig 02 B) quando comparados aos animais eutiroideos, dados sugestivos de uma desorganização do citoesqueleto, já que, a maior quantidade de actina está presente no sobrenadante que abriga a forma não polimerizada $(\mathrm{G})$ dessa proteína.

A administração aguda de T3 (30 min) a animais hipotiroideos promoveu uma reversão do estado descrito acima, ou seja, aumentou o conteúdo de actina no precipitado e o diminuiu na fração do sobrenadante, sugerindo uma reorganização do citoesqueleto (Fig 02 A e B).

A análise estatística do conteúdo de actina na fração do precipitado (Actina $\mathrm{F}$ ) entre os animais hipotiroideos tratados com salina e os tratados com T3 mostrou que a diferença entre eles foi significativa $(\mathrm{p}<0.05)$. 

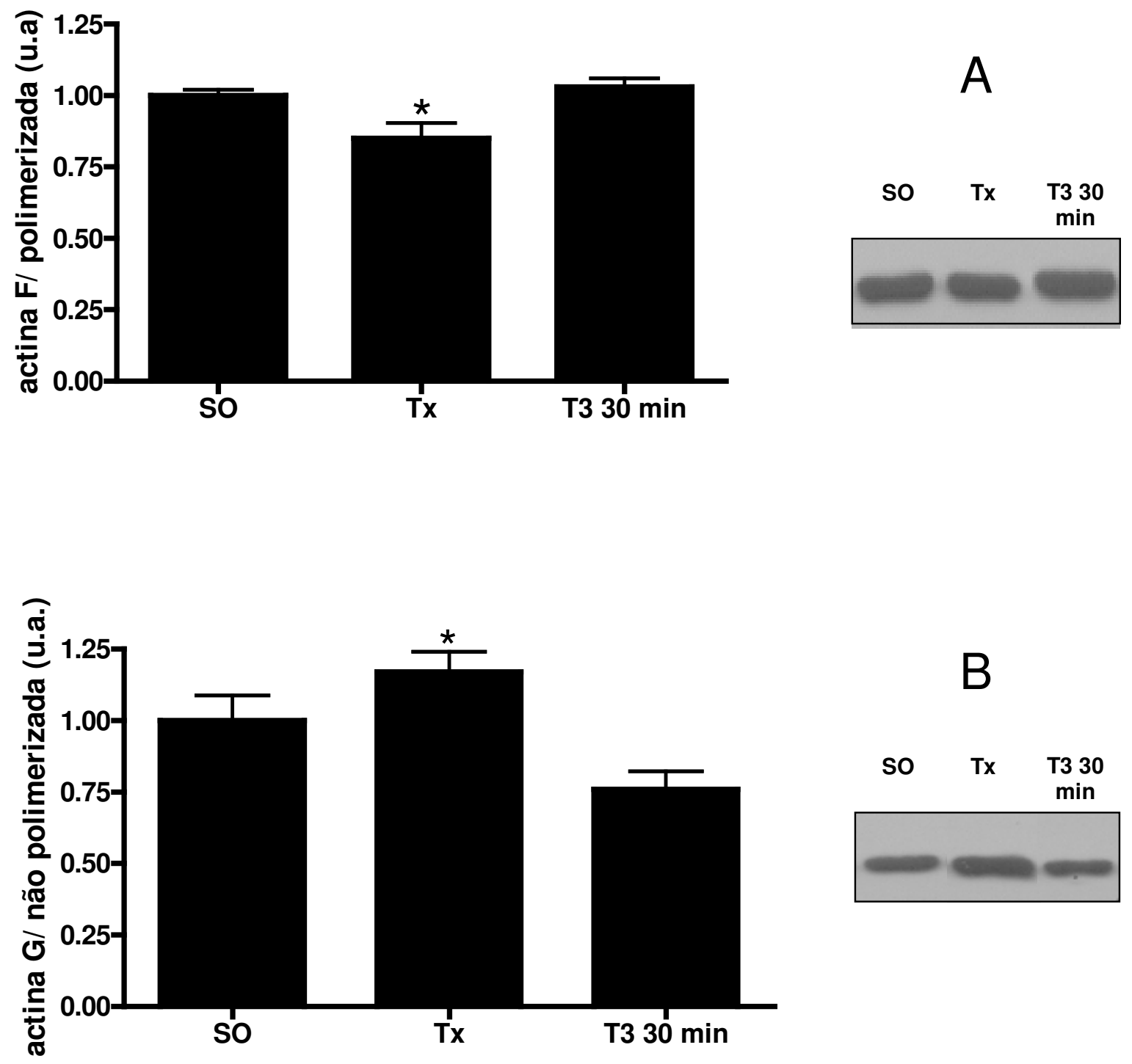

Figura 02: Avaliação da expressão hipofisária de actina no precipitado (actina F: polimerizada) e sobrenadante (actina G: não polimerizada) de ratos eutiroideos (SO), hipotiroideos tratados com salina (Tx) ou com T3 (T3 $30 \mathrm{~min}$ ). Em $\underline{\mathbf{A}}$ temos representada a expressão da actina $\mathrm{F}$ e em $\underline{\mathbf{B}}$ a da actina $\mathrm{G}$. Os blots referentes ao conteúdo de actina estão do lado de cada gráfico. Foram realizados quatro experimentos $(\mathrm{N}=10)$. Os dados representam a média $\pm \mathrm{EPM}$ da densitometria dos blots, em unidades arbitrárias (ua). A: *p $<0.05$ vs SO e T3 30 min. $\underline{\mathbf{B}}: * \mathrm{p}<0.05$ vs T3 $30 \mathrm{~min}$ 
3.3 Efeito do T3 sobre a taxa de associação de eEF $1 \alpha$ ao citoesqueleto de actina: Análise do conteúdo de eEF 1 nas frações polimerizada (actina F) e não polimerizada da actina (actina $G$ ).

Quando avaliamos o conteúdo de eEF $1 \alpha$ na fração correspondente ao precipitado do fracionamento de actina (porção polimerizada) observamos no grupo hipotiroideo uma redução significativa neste parâmetro, em relação aos demais grupos experimentais (Fig 03 A). Entretanto, embora tenhamos observado uma redução no conteúdo de eEF $1 \alpha$ associado a actina G (não polimerizada) nas hipófises dos animais hipotiroideos tratados com T3, em relação aos animais eutiroideos e hipotireoideos, essa diferença não foi significativa (Fig 03 B).

De qualquer forma, esses dados sugerem que o T3 aumenta a ligação desse fator de alongamento ao citoesqueleto de actina, o que pode levar à importantes repercussões sobre a estabilidade e a tradução do transcrito, conforme será discutido adiante. 

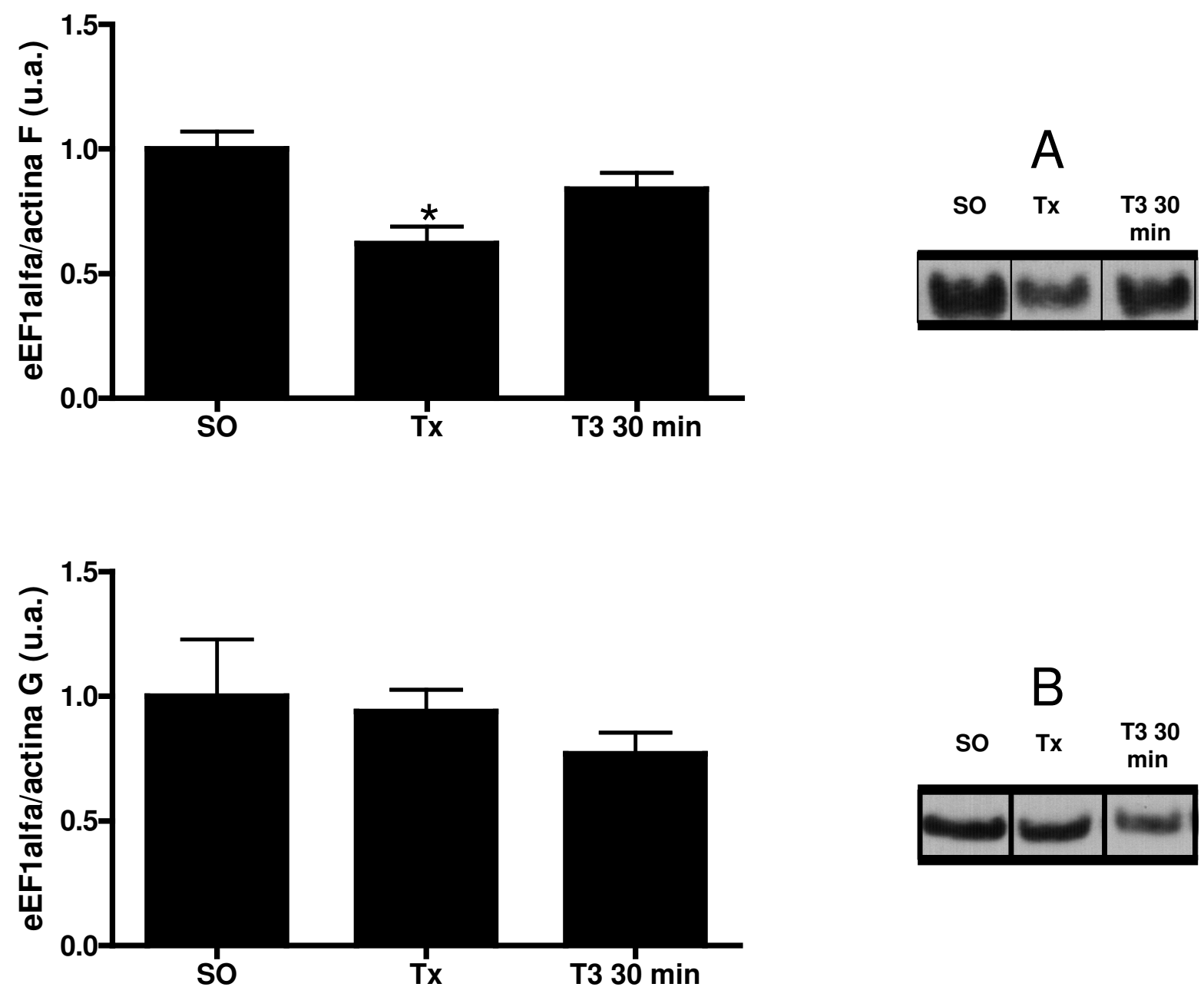

FIGURA 03: Avaliação do conteúdo de eEF $1 \alpha$ ligado ao citoesqueleto de actina em hipófise de ratos eutiroideos (SO) e hipotiroideos tratados com salina (Tx) ou com T3 (T3 $30 \mathrm{~min}$ ). Em $\underline{\mathbf{A}}$ temos representada a expressão da actina $\mathrm{F}$ e em $\underline{\mathbf{B}}$ a da actina $\mathrm{G}$, obtidas no precipitado e sobrenadante, respectivamente. Os blots referentes ao conteúdo de eEF $1 \alpha$ estão ao lado de cada gráfico. Foram realizados quatro experimentos $(\mathrm{N}=12)$. Os dados representam a média \pm EPM da densitometria dos blots, em unidades arbitrárias (ua). *p <0.05 vs SO e T3 30 min. 
3.4 Efeito do T3 sobre a associação do mRNA do GH ao citoesqueleto de actina. Análise do conteúdo de mRNA do GH na fração polimerizada da actina (actina F).

Num primeiro momento, realizamos este estudo avaliando a expressão do mRNA do GH, por Northern blotting, na fração correspondente à actina polimerizada (actina F), quando observamos que os animais eutiroideos apresentavam uma grande quantidade de mRNA de GH nesta fração, ou seja, associado ao citoesqueleto (dados não mostrados). Porém, esta mesma técnica não foi sensível o suficiente para detectar a expressão de mRNAs de $\mathrm{GH}$ associados ao citoesqueleto nos grupos Tx tratados com salina ou T3, razão pela qual passamos a utilizar o método de real time $P C R$, que é específico para avaliação da expressão de mRNAs pouco abundantes.

Quando comparados com os animais eutiroideos, os animais Tx aprensentam pouco mRNA de GH associados ao citoesqueleto (dados não apresentados no gráfico). Em relação aos animais Tx saline, os Tx tratados com T3 (30 min) apresentam muito pouco mRNA de GH associado ao citoesqueleto; o tratamento agudo com T3 elevou o conteúdo de mRNA de GH associado ao citoesqueleto em torno de $70 \%$ (Fig 04). 


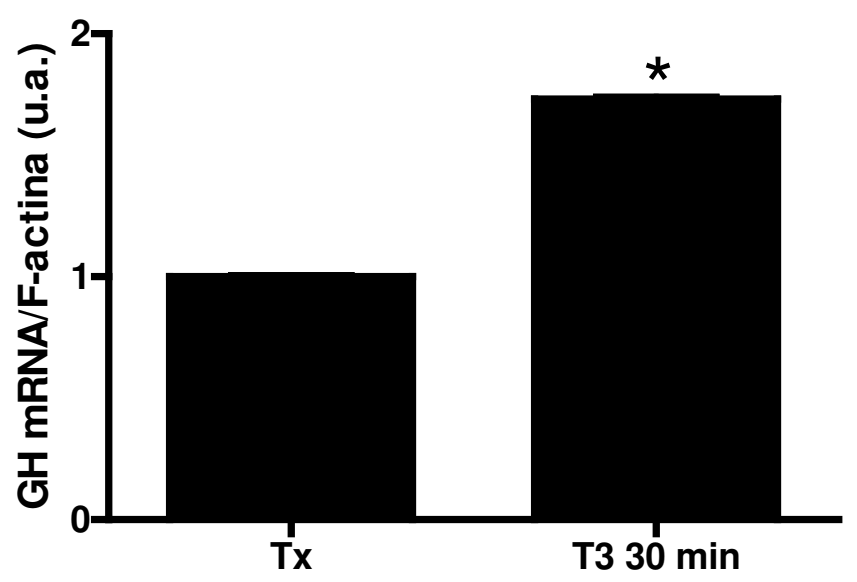

Figura 04: Estudo da associação do mRNA de GH ao citoesqueleto (actina F), por meio da avaliação da sua expressão por real time PCR. Os valores obtidos para o mRNA de GH foram normalizados pelo mRNA de ciclofilina. Os dados representam a média \pm EPM das medidas de CT do real time PCR, em unidades arbitrárias (ua). Foram realizados dois experimentos e os dados considerados significativos apresentaram $\mathrm{p}<0.001$. 
3.5 Efeito do T3 sobre a expressão hepática do mRNA do IGF-I por real time PCR. Análise do efeito do T3 sobre a secreção de GH.

A avaliação da expressão do mRNA de IGF-I no fígado dos animais teve como objetivo aferir indiretamente o grau de secreção de GH nos diferentes grupos experimentais. Observa-se na figura 05, que nos animais Tx a expressão gênica de IGF-I encontra-se diminuída, dado indicativo de uma baixa secreção de $\mathrm{GH}$, por nós atribuída em função dos dados de imunohistoquímica anteriormente descritos. Entretanto, o tratamento de animais Tx com T3 promoveu aumento do conteúdo de IGF-I no fígado destes animais após 30 e 60 minutos. 


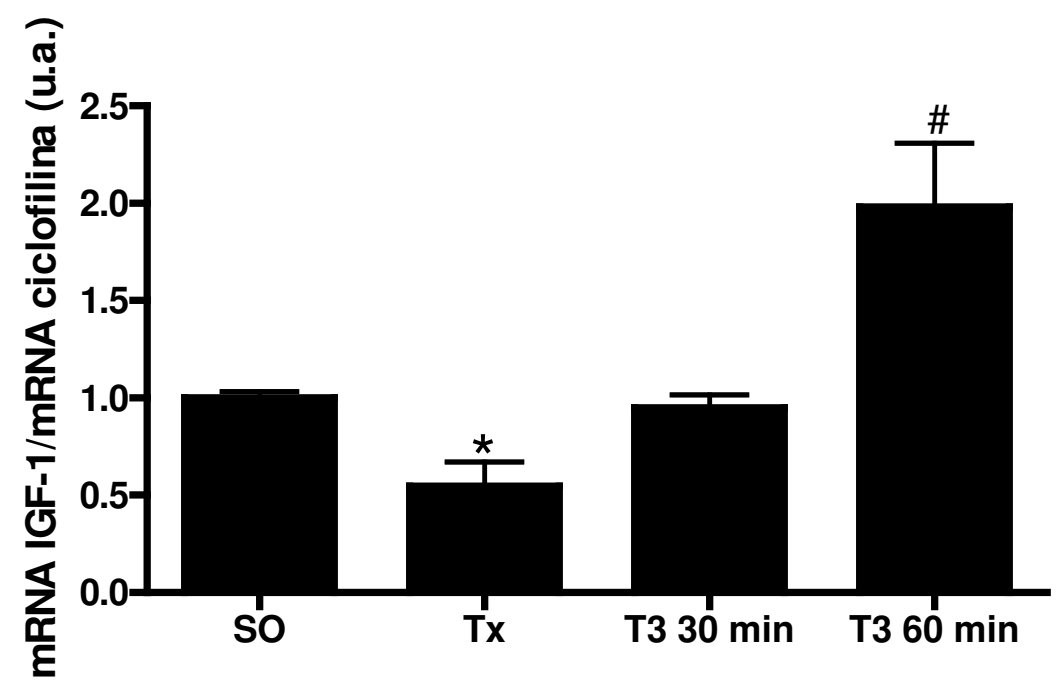

Figura 05: Avaliação da expressão gênica de IGF-I no fígado de ratos eutiroideos (SO) e hipotiroideos tratados com salina (Tx) ou com T3 por $30 \mathrm{~min}$ (T3 $30 \mathrm{~min}$ ) ou $60 \mathrm{~min}$ (T3 $60 \mathrm{~min}$ ). O conteúdo de mRNA de IGF-I foi determinado por real time PCR e os valores obtidos foram normalizados pelo mRNA da ciclofilina. Foram realizados dois experimentos $(\mathrm{N}=7)$._Os dados representam a média \pm EPM das medidas de CT, em unidades arbitrárias (ua). * p $<0,01$ vs SO e T3 $30 \mathrm{~min}$; \# p $<0.001$ vs demais grupos. Os dados considerados significativos apresentaram $p<0.001$ (\#) e p $<0.01(*)$ em relação aos demais grupos. 


\section{DISCUSSÃO}

Os HTs exercem seus efeitos biológicos por meio de ações nucleares e extra-nucleares. Essas últimas explicam os rápidos efeitos desses hormônios em processos, tais como, estabilidade e tradução de mRNAs, que foram alvos do presente estudo. O citoesqueleto participa desses processos por ancorar transcritos e protegê-los da degradação, assim como por permitir a associação de fatores de tradução e proteínas ribossomais à ele, o que otimiza a síntese protéica. Desta forma, a manutenção da organização dessa estrutura é fundamental para que a síntese protéica se dê adequadamente, bem como para que o tráfego de vesículas intracelulares, algumas responsáveis por direcionar proteínas para a membrana plasmática ou ainda pela secreção de hormônios, seja efetuado com sucesso.

Os HTs vem sendo apontados como um dos fatores que participam do controle da organização do citoesqueleto. Estudos desenvolvidos no nosso laboratório demonstraram intenso desarranjo do citoesqueleto de actina em somatotrofos de ratos hipotiroideos, (caracterizado por aumento do conteúdo de actina $\mathrm{G}$ e diminuição da $\mathrm{F}$ ), e sua reverão após 30 min da administração de doses suprafisiológicas de T3. O fato do T3 ter promovido aumento do conteúdo de proteína $\mathrm{F}$ e concomitante redução da $\mathrm{G}$, sem alterar o conteúdo total da actina, indica que o hormônio propiciou o rearranjo dessas proteínas, o que aponta claramente para uma ação não genômica (GOULART DA SILVA et al., 2006).

Esses achados forneceram embasamento para a interpretação de dados anteriores, que demonstraram que a reduzida expressão do mRNA do GH observada no hipotiroidismo era rapidamente $(30 \mathrm{~min}$ ) incrementada pela administração de doses suprafisiológicas de T3. Este aumento da expressão do mRNA do GH foi considerado como decorrente do aumento da sua estabilidade, já que, em paralelo, detectou-se um aumento da poliadenilação deste transcrito (VOLPATO et al., 2000). Cogitou-se a participação do citoesqueleto no processo, uma vez que várias proteínas envolvidas com a poliadenilação e estabilização de transcritos encontram-se associadas ao citoesqueleto.

A análise imunohistoquímica dos somatotrofos de animais hipotiroideos revelou uma generalizada redução da expressão do GH e leve marcação específica na periferia das células. Essa marcação praticamente desapareceu após 30 min da administração do T3, quando, então, 
forte marcação para o GH pode ser detectada na região perinuclear dos somatotrofos, sítio da maquinaria de tradução de mRNAs e da síntese protéica, sugerindo a participação do T3 na secreção e síntese de GH. Esses achados foram acompanhados, respectivamente, de desarranjo e rearranjo do citoesqueleto de actina, (GOULART DA SILVA et al., 2006) o que nos levou a desenvolver o presente estudo, cujo objetivo foi avaliar a taxa de tradução do mRNA do GH e a secreção deste hormônio, bem como caracterizar alguns eventos que poderiam associar o citoesqueleto com a estabilização e tradução do transcrito do GH nas condições experimentais mencionadas.

Nossos dados demonstraram que a tradução do mRNA do GH assim como a secreção deste hormônio encontram-se comprometidas no estado hipotiroideo, condição revertida prontamente após a administração aguda de T3. Por tratar-se de efeitos rápidos dos HTs e em etapas da regulação da expressão gênica claramente definidas como pós-transcricionais sugerimos ser esse um mecanismo de ação não genômico. Cumpre destacar que todas essas alterações estiveram ligadas a mudanças no estado de polimerização da actina do citoesqueleto, o que aponta para a importância dessa estrutura nessas funções, corroborando nossos estudos anteriores.

As conclusões acerca da ação do T3 na taxa de tradução do mRNA do GH se basearam, principalmente, na análise do perfil polissomal de hipófises dos animais dos diferentes grupos experimentais, procedimento que nos permitiu avaliar a quantidade de transcritos recrutados para a síntese protéica, no momento imediatamente após o sacrifício dos animais. Observamos um elevado conteúdo de mRNA de GH na fração polissomal de hipófise de ratos eutiroideos (Fig 01A), sugerindo que, praticamente todo o transcrito produzido foi direcionado para a maquinaria traducional. Todavia, a análise do perfil polissomal de animais hipotiroideos (Tx) mostrou diminuição intensa da expressão do mRNA de GH nessa fração (Fig 01B), o que corrobora os dados da literatura indicativos de redução de síntese de GH nessas condições. Observou-se também que praticamente todo o pouco conteúdo de mRNA de GH presente na hipófise do animal Tx foi detectado nos polissomos, já que nenhum sinal radiográfico do transcrito foi observado na fração livre do perfil, ou seja, na fração onde os mRNAs não estão ligados a subunidades ribossomais ou ribossomos. 
Sabe-se que a expressão do gene do GH é induzida pelos HTs, o que faz com que nos estados de hipotiroidismo a transcrição desse gene apresente-se intensamente reduzida, o que, dependendo da fase de vida do indivíduo, leva a repercussões no crescimento, explicando, ao menos em parte, a importância fisiológica dos HTs sobre o crescimento. Dessa forma, era esperado que a taxa de tradução do mRNA do GH estivesse reduzida no grupo Tx quando comparada ao grupo controle, conforme nos mostrou o perfil polissomal. Considerando ainda que os animais se apresentavam hipotiroideos há aproximadamente 20 dias, é possível que a redução do conteúdo de transcritos nos polissomos seja reflexo da baixa taxa transcricional e de um turnover reduzido do mesmo nessa condição. Em outras palavras, os dados isolados do perfil relacionados a esses dois grupos são insuficientes para que creditemos ao T3 uma ação não genômica específica sobre essa etapa. Porém, essa possibilidade torna-se palpável, quando levamos em conta a desorganização do citoesqueleto apontada em estudos anteriores, bem como os resultados obtidos quando da avaliação específica da expressão de fatores relacionados à tradução nesta estrutura, conforme discutiremos oportunamente.

Por outro lado, o tratamento agudo de ratos Tx com T3 (30 min), seguido de análise do perfil polissomal das suas hipófises, revelou um aumento do conteúdo do transcrito nos polissomos, sugerindo um rápido direcionamento do mRNA de $\mathrm{GH}$ aos mesmos, e sua tradução à proteína GH (Fig 01C). Esse dado dá suporte aos achados anteriores obtidos pelo nosso grupo que demonstrou aumento da expressão gênica do GH nessas mesmas condições, atribuindo esse efeito ao possível aumento da estabilidade do transcrito, já que ele se apresentou com maior grau de poliadenilação. De fato, mRNAs mais estáveis podem gerar maior quantidade das proteínas que codificam, já que além de apresentarem aumento de sua meia vida, ancoram com mais eficiência na maquinaria de tradução. Vale reiterar que essas alterações ocorreram concomitantemente à reorganização do citoesqueleto de actina do somatotrofo, cujo papel será abordado adiante.

A tradução é um evento complexo e bem dispendioso para a célula, já que boa parte de sua energia é direcionada para a síntese protéica. Alguns componentes celulares são essenciais para que este processo ocorra, dentre eles, o citoesqueleto. Estudos com os polissomos revelaram que estas estruturas da maquinaria traducional estão associadas ao citoesqueleto, dado que fortalece ainda mais a importância deste na tradução de mRNAs (HESKETH, 1994; VEDELER, 
1991). Desta forma, um citoesqueleto desorganizado pode prejudicar a tradução de mRNAs e, consequentemente, a síntese protéica.

A presença de polissomos per se associados a elementos do citoesqueleto já é um grande indicativo do papel desta estrutura na tradução. Isto é importante, pois o citoesqueleto pode compartimentalizar a síntese protéica, direcionando-a para os locais onde as proteínas podem exercer sua função. Um exemplo disso, é a compartimentalização da síntese de actina (LYUBIMOVA et al., 1997). Nesse caso, o mRNA da actina é preso ao citoesqueleto, direcionado para certas regiões no intracelular, traduzido e a proteína actina utilizada para formar microfilamentos (lamelipódios e filopódios), estruturas importantes para a célula durante, por exemplo, seu processo de migração.

Outro fator a se levar em consideração é que não somente os polissomos são encontrados ligados ao citoesqueleto, mas vários fatores de iniciação da tradução e alongamento da cadeia polipeptídica, como o complexo eIF4F, eIF3, eIF2, eEF2 e eEF1 $\alpha$ (SHANINA et al., 2001; PINCHEIRA et al., 2001; SHESTAKOVa et al., 1993; RYAZANOV et al., 1991; SMART et al., 2003; WILLETT et al., 2006). A presença de todos esses fatores de iniciação e alongamento ligados ao citoesqueleto torna-o peça fundamental para que o transcrito seja traduzido.

$\mathrm{O}$ eEF1 $\alpha$ é um dos fatores de tradução que estão envolvidos com o alongamento da cadeia polipeptídica durante a tradução e, assim como outros fatores, ele também está ligado ao citoesqueleto. Entretanto, esta interação está envolvida com outro evento essencial para a eficiência traducional que é o ancoramento de mRNAs ao citoesqueleto, fato que confere maior estabilidade aos transcritos. Apesar de pouco explorada, esta segunda função do eEF1 $\alpha$ tem sido apontada em adenocarcinoma mamário de ratas - MTLn3 e MTC (Liu et al., 2002), o que não exclui a possibilidade de que, dependendo do tipo celular ou espécie, outras proteínas estejam envolvidas com essa função de ancoramento (JANSEN, 1999).

Os estudos que desenvolvemos com o citoesqueleto e eEF1 $\alpha$ demonstraram que nos animais Tx o conteúdo de eEF1 $\alpha$ associado a actina $\mathrm{F}$ está reduzido na hipófise (Fig 03A). É interessante recolocar que nesse estado tiroideano (Tx) o citoesqueleto de somatotrofos está desorganizado, o que foi reiterado neste estudo, conforme mostra a figura 02A. Desta forma, acreditamos que esta desorganização tenha levado à diminuição da interação do eEF1 $\alpha$ com o 
citoesqueleto, prejudicando assim a associação dos transcritos com a actina $\mathrm{F}$ o que, além de provocar redução da síntese protéica, torna esses mRNAs vulneráveis à ação de exorribonucleases (RNases). Apesar de estudos apontarem para um aumento da cauda poli A do transcrito de $\mathrm{GH}$ no rato $\mathrm{Tx}$, o que torna esse mRNA mais estável em um momento onde há redução de sua transcrição (MURPHY et al., 1992), deve se levar em consideração que a manutenção da estabilidade do mRNA depende primariamente dos fatores adicionais que acabamos de apontar.

Essa hipótese ganha força a partir dos resultados obtidos pela análise do conteúdo de mRNA de GH ligado a actina $\mathrm{F}$ no grupo Tx, onde observamos que pequena parcela de mRNA de GH se encontra associada (Fig 04), resultado que pode estar vinculado ao pouco eEF1 $\alpha$ conectado ao citoesqueleto, detectado também nos animais Tx (Fig 03A), bem como ao menor conteúdo de mRNA na fração polissomal obtida a partir de hipófises desses animais. (Fig 01)

A reposição de T3 em concentrações supra-fisiológicas elevou o conteúdo de eEF1 $\alpha$ (Fig 03A) assim como de mRNA de GH (Fig 04) associado a actina F. A concomitante interação entre eEF1 $\alpha$ e mRNA de GH ao citoesqueleto poderia justificar a estabilidade deste transcrito, efeito que se soma ao aumento da cauda poli A do mRNA de GH, e também aumenta a eficiência da sua tradução. Esse rearranjo do citoesqueleto também incrementou o direcionamento do transcrito aos polissomos, o que já foi discutido.

Assim, a reorganização do citoesqueleto induzida pelo T3, demonstrada por histoquímica e pela determinação, por western blotting, do conteúdo de actina $G$ (não polimerizada) e actina $F$ (polimerizada) em preparações hipofisárias dos animais deste grupo experimental, poderia explicar o aumento da cauda poli A do mRNA de GH, já que as proteínas envolvidas com esse processo, a poli A polimerase (PAP) e poly A binding protein (PABP) estão associadas ao citoesqueleto. Porém, conforme discutido, esta não é a única via para se explicar a estabilidade do transcrito do $\mathrm{GH}$, já que concomitantemente à reorganização do citoesqueleto, há uma maior interação entre eEF1 $\alpha$ e actina $\mathrm{F}$, o que favorece a tradução do transcrito e a síntese de proteínas, já que o eEF1 $\alpha$ é um dos fatores envolvidos no alongamento da cadeia polipeptídica. De fato, observamos, em paralelo a essas evidências que, após o tratamento agudo com T3, houve maior recrutamento de mRNA do GH para os polissomos, os quais também encontram-se associados ao 
citoesqueleto. Não podemos deixar de ressaltar que um segundo papel recentemente atribuído ao eEF1 $\alpha$, é que ele também se liga à mRNAs recém sintetizados, de modo que esta associação entre citoesqueleto e eEF1 $\alpha$ também contribui para a união do mRNA de GH à actina $\mathrm{F}$, dando a esse transcrito maior estabilidade e, por conseguinte, reduzindo a sua degradação, o que pode levar a uma maior produção de proteínas.

Entretanto, a dissociação do eEF1 $\alpha$ do citoesqueleto também representa um passo importante para a síntese protéica, bem como para a secreção de produtos celulares, como demonstrado no estudo a seguir, que avalia o papel da Rho-quinase. A Rho-quinase é uma enzima que participa da via de sinalização para polimerização de actina (CHIHARA et al., 1997), porém observou-se que ela pode fosforilar o eEF1 $\alpha$, diminuindo a afinidade deste fator de alongamento à actina F, tornando-o livre para associar-se ao tRNA e transportá-lo para os polissomos. Além disso, observou-se que essa dissociação deixa livres sítios da actina F, o que permite a interação do citoesqueleto com proteínas motoras, as quais participam do processo de secreção de várias substâncias presentes nas células (IZAWA et al., 2000).

Esse processo, também conhecido por exocitose é fundamental para atividade biológica da célula, de forma que, qualquer situação que altere a integridade do citoesqueleto, levando a desestabilização de seus filamentos protéicos, prejudicará a secreção celular.

Sabe-se que os somatotrofos de ratos Tx apresentam um citoesqueleto desorganizado e ao analisar a distribuição intracelular dos grânulos de GH observamos que o pouco GH expresso nestas células apresentava-se concentrado em grânulos na sua periferia, sugerindo comprometimento da sua secreção. A administração de T3 promoveu rearranjo do citoesqueleto do somatotrofo e reduziu, concomitantemente, a marcação de GH na periferia da célula, indicando estímulo da secreção hormonal pelo T3 (GOULART DA SILVA et al., 2006).

Para avaliar se o GH foi secretado após a reorganização do citoesqueleto estudamos o grau de expressão de um dos genes regulados por ele, o IGF-I. Este gene é expresso em vários tecidos, inclusive no fígado, o qual é o principal órgão-alvo do $\mathrm{GH}$, uma vez que apresenta a maior expressão de receptores de $\mathrm{GH}$. O GH interage com esses receptores promovendo rápida indução do gene do IGF-I, considerado o principal mediador dos efeitos do GH no crescimento pós-natal, sendo portanto o principal parâmetro indicativo de que o GH está sendo liberado e 
exercendo seus efeitos biológicos apropriadamente. Apesar do T3 também ter sido apontado como indutor da expressão gênica do IGF-I, demonstrou-se que esse efeito é totalmente dependente da sua ação sobre a expressão do GH, uma vez que o bloqueio da expressão/liberação do GH ou mesmo mediante hipofisectomia, o efeito do T3 sobre o gene do IGF-I fica completamente abolido (NÄNTÖ-SALONEN et al., 1993). Desta forma, avaliamos a expressão hepática do mRNA de IGF-I dos animais eutiroideos e dos hipotiroideos após 30 min e 60 min da administração de T3 ou salina.

Observamos que a expressão hepática de mRNA de IGF-I nos animais Tx apresentou-se extremamente baixa, mas que, após 30 min da administração de T3 ela aumenta ao nível do animal controle, sendo o efeito ainda mais proeminente após 60 minutos da administração de T3 (Fig 05). Esses dados corroboram nossos resultados de imuno-histoquímica indicativos de redução de secreção de GH no hipotiroidismo e aumento dela após $30 \mathrm{~min}$ da administração de T3, e fortalecem nossa hipótese inicial do envolvimento do citoesqueleto nestes eventos, já que os dados apontam fortemente uma relação entre a sua reorganização desencadeada não genomicamente pelo T3 e a secreção do GH.

O conjunto dos dados apresentados descreve uma ação não genômica do T3, até então desconhecida, no controle da expressão do gene do GH e da secreção deste hormônio. 


\section{REFERÊNCIAS BIBLIOGRÁFICAS}

ALKHAMI, A. M.; CUSIMANO, M.; KOVACS, K.; BILBAO, J. M.; HORVATH, E; SINGER, W. Cytology of pituitary thyrotroph hyperplasia in protracted primary hypothyroidism. Pituitary, v. 1, p. 291-295, 1999.

BIANCO, A. C.; NUNES, M. T.; DOUGLAS, C. R.; TADEU, M. A.; AURIEMO, C. Hypothalamic-pituitary-thyroid function in rats undergoing colesterol feeding. Neuroendocrinol. Lett., v. 5, p. 93-98, 1983.

BRADFORD, M. M. A rapid and sensitive method for the quantification of microgram quantities of protein utilizing the principle of protein-dye binding. Anal Biochem., v. 7, p. 248-254, 1976.

CAO, X.; KAMBE, F.; MOELLER, L.C.; REFETOFF, S.; SEO, H. Thyroid hormone induces rapid activation of Akt/protein Kinase B-mammalian target of rapamycin-p70S6K cascade through phosphatidylinositol 3-kinase in human fibroblasts. Mol. Endocrinol., v. 19, p.102-112, 2005.

CIMMINO, M.; MION, F.; GOGLIA, F.; MINAIRE, Y.; GELOEN, A. Demonstration of in vivo metabloic effects of 3,5-di-iodothyronine. J. Endocrinol., v. 149, p.319-325, 1996.

CONDEELIS, J. Elongation factor 1 alpha, translation and the cytoskeleton. Trends Biochem Sci., v. 20, p. 169-170, 1995.

CHIHARA, K.; AMANO, M.; NAKAMURA, N.; YANO, T.; SHIBATA, M.; TOKUI, T.; ICHIKAWA, H.; IKEBE, M.; KAIBUCHI, K. Cytoskeletal rearrangements and transcriptional activation of $c$-fos serum response element by Rho-Kinase. J. Biol. Chem., v. 272, p. 2512125127, 1997.

CHOMCZYNSKI, P.; SACCHI, N. Single-step method of RNA isolation by acid guanidinium thiocyanante-phenol-chloroform extraction. Anal. Biochem., v. 162, p. 156-159, 1987.

CHIN, E. R., OLSON, E. N., RICHARDSON, J. A., YANG, Q., HUMPHRIES, C., SHELTON, J. M., WU, H., ZHU, W., BASSEL-DUBY, R., WILLIAMS, R. S. A calcineurin-dependent transcriptional pathway controls skeletal muscle fiber type. Genes Dev. v. 12, p. 2499-2509, 1998.

DAVIS, F. B.; MOUSA, S. A.; O’CONNOR, L.; MOHAMED, S.; LIN, H. Y.; CAO, H. J.; DAVIS, P. J. Proangiogenic action of thyroid hormone is fibroblast growth factor-dependent and is initiated at the cell surface. Circ. Res., v. 94, p. 1500-1506, 2004.

DAVIS, P. J.; DAVIS, F. B. Nongenomic actions of thyroid hormone. Thyroid, v. 6, p. 497-504, 1996. 
DELHASE, M.; RAJAS, F.; VERDOOD, P.; REMY, C.; CHEVALLIER, P.; VELKENIERS, B.; TROUILLAS, J.; et al. Prolactin and growth hormone mRNA and protein characterization in SMtTW rat pituitary tumours. J. Endocrinol., v. 15, p. 233-245, 1995.

FARWELL, A. P.; DUBORD-TOMASETTI, S. A.; PIETRZYKOWSKI, A. Z.; STACHELEK, S. J.; LEONARD, J. L. Regulation of cerebellar neuronal migration and neurite outgrowth by thyroxine and 3,3',5'-triiodothyronine. Brain Res. Brain Res., v. 154, p. 121-135, 2005.

FARWELL, A. P.; LEONARD, J. L. Dissociation of actin polymerization and enzyme inactivation in the hormonal regulation of type II iodothyronine 5 - deiodinase activity in astrocytes. Endocrinology, v. 131, p. 721-728, 1992.

FARWELL, A. P.; LYNCH, R. M.; OKULICZ, W. C.; COMI, A. M.; LEONARD, J. L. The actin cytoskeleton mediates the hormonally regulated translocation of type II iodothyronine 5 'deiodinase in astrocytos. J. Biol. Chem., v. 265, p. 18546-18553, 1990.

GIANNOCCO, G.; DOS SANTOS, R. A.; NUNES, M. T. Thyroid hormone stimulates myoglobin gene expression in rat cardiac muscle. Mol. Cell Endocrinol., v. 226, p. 19-26, 2004.

GOUVEIA, C. H.; SCHULTZ, J. J.; BIANCO, A. C.; BRENT, G. A. Thyroid hormone stimulation of osteocalcin gene expression in ROS 17/2.8 cells is mediated by transcriptional and post-transcriptional mechanisms. J. Endocrinol., v. 170, p. 667-675, 2001.

HALL, A. Rho GTPases and the actin cytoskeleton. Science, v. 279, p. 509-514, 1998.

HALLER, K.; RAMBALDI, I.; DANIELS, E.; FEATHERSTONE, M.; Subcellular localization of multiple PREP2 isoforms is regulated by actin, tubulin, and nuclear export. J. Biol. Chem. v. 279, p. 49384-49394, 2004.

HEFCO, E.; KRULICH, L; ILLNER, P.; LARSEN, P. R. Effect of acute exposure to cold on the activity of the hypothalamic-pituitary-thyroid system. Endocrinology, v. 104, p. 1185-1195, 1975.

HESKETH, J. E. Sorting of messenger RNAs in the cytoplasm: mRNA localization and the cytoskeleton. Exp. Cell Res., v. 225, p.221-236, 1996.

HORVATH E.; KOVACS K.; SCHEITHAUER B. W. Pituitary hyperplasia. Pituitary, v. 1, p. 169-179, 1999.

IWASAKI, Y.; MORISHITA, M.; ASAI, M.; ONISHI, A.; YOSHIDA, M.; OISO, Y.; INOUE, K. Effects of hormones targeting nuclear receptors on transcriptional regulation of the growth hormone gene in the MtT/S rat somatotrope cell line. Neuroendocrinology, v. 79, p.229-236, 2004.

IZAWA, T.; FUKATA, Y.; KIMURA, T.; IWAMATSU, A.; DOHI, K.; KAIBUCHI, K. Elongation factor $-1 \alpha$ is a novel substrate of Rho - associated kinase. Biochem. Biophys. Res. Commun., v. 278, p. 72-78, 2000. 
KAVOK, N. S.; KRASILNIKOVA, O. A.; BABENKO, N. A.; Thyroxine signal transduction in liver cells involves phospholipase $\mathrm{C}$ and phospholipase $\mathrm{D}$ activation. Genomic independent action of thyroid hormone. BMC Cell Biol. v. 2, p.5, 2001.

KAWAMINAMI, M.; TSUCHIWAMA, Y.; SAITO, S.; KATAYAMA, M.; KURUSU, S.; HASHIMOTO, I. Gonadotropin-releasing hormone stimulates annesein 5 messenger ribonucleic acid expression in the anterior pituitary cells. Biochem. Biophys. Res. Commun, v.8, p.915-920, 2002.

KOHRLE, J. The selenoenzyme family of deiodinase isozymes controls local thyroid hormone availability. Rev. Endocr. Metab. Disord., v. 1, p. 49-58, 2000.

LAMMELI, U. K. Cleavage of structural proteins during the assembly of the head of bacteriophage T4. Nature, v. 227, p. 680-685, 1970.

LANNI, A.; MORENO, M.; CIOFFI, M.; GOGLIA, F. Effect of 3,3'-di-iodothyronine and 3,5di-iodothyronine on rat liver mitochondria. J. Endocrinol., v. 136, p. 59-64, 1993.

LEI, J.; NOWBAR, S.; MARIASH, C. N.; INGBAR, D. H. Thyroid hormone stimulates Na-KATPase activity and its plasma membrane insertion in rat alveolar epithelial cells. Am. J. Physiol. Lung Cell Mol. Physiol., v. 285, p. L762-L772, 2003.

LEONARD, J. L.; FARWELL, A. P. Thyroid hormone-regulated actin polymerization in brain. Thyroid, v. 7, p.147-151, 1997.

LIPSHITZ H. D.; SMIBERT C. A. Mechanisms of RNA localization and translation regulation. Curr. Opin. Gen. Dev., v. 10, p. 476-488, 2000.

LIU, G; GRANT, W. M.; PERSKY, D.; LATHAM, V. M. jr; SINGER, R. H.; CONDEELIS, J. Interactions of elongation factor 1 alpha with F-actin and beta-actin mRNA: implications for anchoring mRNA in cell protrusions. Mol. Biol. Cell, v. 13, p.579-592, 2002.

LIVAK, K.J.; SCHMITTGEN, T. D. Analysis of relative gene expression data using real-time quantitative PCR and the 2(-Delta Delta C(T) Method. Methods, v. 25, p. 402-408, 2001.

LLOYD, R. V.; CANO, M.; LANDEFELD, T. D. The effects of estrogens on tumor growth and on prolactin and growth hormone mRNA expression in rat pituitary tissues. Am. J. Pathol., v. 133, p. 397-406, 1988.

LOWRY, O.; ROSEBROUGH, N. J.; FARR, L. A.; RANDALL, R. J. - Protein measurement with the folin phenol reagent. J. Biol. Chem., v. 193, p. 265-275, 1951.

MANIATIS, T., FRITSCH, E. F., SAMBROOK, J. Molecular cloning: a laboratory manual. $\mathrm{v}$ 2, 3 ed. New York: Cold Spring Harbor Laboratory Press, 1989. 
MASSAELI, H.; HURTADO, C.; AUSTRIA, J. A.; PIERCE, G. N. Oxidized low-density lipoprotein induces cytoskeletal disorganization in smooth muscle cells. Am. J. Physiol. heart Circ. Physiol., v.277, p. H2017-H2025,1999.

MEIKLE, A.W. The interrelationship between thyroid dysfunction and hypogonadism in men and boys. Thyroid, v. 14, p. S17-25, 2004.

MEZOSI, E.; SZABO, J.; NAGY, E. V.; BORBELY, A.; VARGA, E.; PARAGH, G.; VARGA, Z.; Nongenomic effect of thyroid hormone on free-radical production in human polymorphonuclear leukocytes. J. Endocrinol., v. 185, p.121-129, 2005.

MOHR, E.; PRAKASH, N.; VIELUF, K.; FUHRMANN, C.; BUCK, F.; RICHTER, D. Vasopressin mRNA localization in nerve cells: characterization of cis-acting elements and transacting factors. Proc. Natl. Acad. Sci . U S A, v. 19, p. 7072-7079, 2001.

MOHR-KAHALY, S.; KAHALY, G., MEVER, J. Cardiovascular effects of thyroid hormones. Z. Kardiol., v. 85, Suppl 6, p. 219-231, 1996.

MOORE, J. M.; GUY, R. K. Coregulator interactions with the thyroid hormone receptor. Mol. Cell Proteomics., v. 4, p. 475-482, 2005.

MÜNCHOW, S.; SAUTER, C.; JANSEN, R. P. Association of the class V myosin Myo4p with a localized messenger RNA in budding yeast depends on She proteins. J. Sci., v. 112, p. 1511$1518,1999$.

NEGRUTSKII, B. S.; El'SKAYA, A. V. Eukaryotic translation elongation factor 1 alpha: structure, expression, functions, and possible role in aminoacyl-tRNA channeling. Prog. Nucleic Acid. Res. Mol. Biol., v.60, p. 47-78, 1998.

NOBES, C.; HALL, A. Regulation and function of the Rho subfamily of small GTPases. Curr. Opin. Genet. Dev., v. 4, p. 77-81, 1994.

PAL, U.; BISWAS, S. C.; SARKAR, P. K. Regulation of actin and its mRNA by thyroid hormones in cultures of fetal human brain during second trimester of gestation. J. Neurochem., v. 69, p. 1170-1176, 1997.

PODDAR, R.; PAUL, S.; CHAUDHURY, S.; SARKAR, P. K. Regulation of actin and tubulin gene expression by thyroid hormone during rat brain development. Brain Res. Mol. Brain Res., v. 35, p 111-118, 1996.

POLIKAR, R.; BURGER, A. G.; SCHERRER, U.; NICOD, P. The thyroid and the heart. Circulation. v. 87, p. 1435-1441, 1993.

POSERN, G.; SOTIROPOULOS, A.; TREISMAN, R. Mutant actins demonstrate a role for unpolymerized actin in control of transcription by serum response factor. Mol. Biol. Cell, v. 13, p. 4167-4178, 2002. 
RIBEIRO, R. C.; APRILETTI, J.W.; WEST, B. L.; WAGNER, R. L.; FLETTERICK, R. J.; SCHAUFELE, F.; BAXTER, J. D. The molecular biology of thyroid hormone action. Ann. N. Y. Acad. Sci., v.30, p.366-389, 1995.

SAFRAN, M.; FARWELL, A. P.; ROKOS, H.; LEONARD, J. L. Structural requirements of iodothyronines for the rapid inactivation and internalization of type II iodothyronine 5 "deiodinase in glial cells. J. Biol. Chem., v. 268, p. 14224-14229, 1993.

SAFRAN, M.; FARWELL, A. P.; LEONARD, J. L. Thyroid hormone-dependent redistribution of the 55-kilodalton monomer of protein disulfide isomerase in cultured glial cells. Endocrinology, v. 131, p.2413-2418, 1992.

SCHRODER, H. C.; ZAHN, R. K.; MÜLLER, W. E. G. Role of actin and tubulin in the regulation of poly (A) polymerase-endoribonuclease IV complex from calf thymus. . J. Biol. Chem.,v. 257, p. 2305-2309, 1982.

SIEGRIST-KAISER, C. A.; JUGE-AUBRY, C.; TRANTER, M. P.; EKENBARGER, D. M.; LEONARD, J. L. Thyroxine-dependent modulation of actin polymerization in cultured astrocytes. J. Biol. Chem.,v. 265, p. 5296-5302, 1990.

SHUPNIK, M. A.; RIDGWAY, E. C.; Triiodothyronine rapidly decreases transcription of the thyrotropin subunit genes in thyrotropic tumor explants. Endocrinology, v. 117, p. 1940-1946, 1985.

STACHELEK, S. J.; KOWALIK, T. F.; FARWELL, A. P.; LEONARD, J. L. Myosin V plays an essential role in the thyroid hormone-dependent endocytosis of type II iodothyronine 5'deiodinase. J. Biol. Chem.,v. 275, p. 31701-31707, 2000.

TEKOTTE, H.; DAVIS, I. Intracellular mRNA localization: motors move messages. Trends in Genetics. v. 18, p. 636-642, 2002.

TOHEI, A. Studies on the functional relationship between thyroid, adrenal and gonadal hormones. J. Reprod. Dev., v. 50, p 9-20, 2004.

TOWBIN, H.; STAEHELIN, T.; GORDON, J. Electrophoretic transfer of protein from polyacrylamide gels to nitrocellulose sheets: Procedure and some applications. Proc. Natl. Acad. Sci., v. 76, p. 4350-4354, 1979.

VAN ALEST, L. and D'SOUZA-SCHOREY, C. Rho GTPases and signaling networks. Genes Dev., v. 11, p. 2295-2322, 1997.

VIDAL, S.; HORVATH, E.; KOVACS, K.; LLOYD, R. V.; SMYTH, H. S. Reversible transdifferentiation: interconversion of somatotrophs and lactotrophs in pituitary hyperplasia. Mod. Pathol. v. 14, p.20-28, 2001. 
VIDAL, S.; HORVATH, E.; KOVACS, K.; COHEN, S. M.; LLOYD, R. V.; SCHEITHAUER, B. W. Transdifferentiation of somatotrophs to thyrotrophs in the pituitary of patients with protracted primary hypothyroidism. Virchows Arch. v. 436, p. 43-51, 2000.

VOLPATO, C. B.; NUNES, M. T. Role of thyroid hormone in the control of growth hormone gene expression. Braz. J. Med. Biol. Res., v.27, p. 126-72, 1994.

VOLPATO, C. B; SHIRAISHI, E. M.; LATRONICO, A. C.; NUNES, M. T. - Thyroid hormone modulates the polyadenylation of growth hormone mRNA in rats. Endocrine Journal, v. 47 (Supl), p.169, 2000.

VOLPATO, C. B.; NUNES, M. T. Functional evidence for the presence of type II 5'- deiodinase in somatotropes and its adaptive role in hypothyroidism. Neuroendocrinology, v. 74, p. 220226, 2001.

WATANABE, T.; NORITAKE, J.; KAIBUCHI, K. Regulation of microtubules in cell migration. Trends Cell Biol. v. 15, p.76-83, 2005.

WOLF, G. The regulation of the thyroid-stimulation hormone of the anterior pituitary gland by thyroid hormone and by 9-cis-retinoic acid. Nutr. Rev., v. 60, p. 374-377, 2002.

YANG, F.; DEMMA, M.; WARREN, V.; DHARMAWARDHANE, S.; CONDEELIS, J. Identification of an actin-binding protein from Dictyostelium as elongation factor 1a. Nature, v. 347, p.494-496, 1990. 